\title{
PALEOCLIMATIC INFERENCES BASED ON WOOD GROWTH INTERRUPTIONS IN LATE TRIASSIC FLOOD DEPOSITS FROM THE SOUTHERNMOST BRAZILIAN GONDWANA
}

\author{
ANELISE MARTA SIEGLOCH @, MARGOT GUERRA-SOMMER (D, \\ CESAR LEANDRO SCHULTZ (D) \& EDUARDO GUIMARAES BARBOZA (D) \\ Programa de Pós-Graduação em Geociências, Universidade Federal do Rio Grande \\ do Sul, IGEO, Av. Bento Gonçalves 9500, 91509-900, Porto Alegre, Brazil. \\ anesiegloch@yahoo.com.br,margot.sommer@ufrgs.br, \\ cesar.schultz@ufrgs.br,eduardo.barboza@ufrgs.br
}

\begin{abstract}
The goals of this study were to establish patterns in a silicified wood assemblage to depict the evolution patterns of the Triassic paleoclimate in southern Brazilian Gondwana during an interval of global arid to semi-arid climatic context, and the taphonomic process that led to the preservation of the so-called "Petrified Forest", which is preserved in the central area of the state of Rio Grande do Sul. Analyses were developed with an assemblage of 13 permineralized conifer wood, using standard thin sections, whose anatomical details were studied in transmitted light. Ground-Penetrating Radar was used to obtain information about the depositional characteristics of the site. Main results are: true growth rings are absent in all samples, and the boundaries of the interruption zones are marked by an abrupt decline in cell diameter, but they are not accompanied by a reduction of cell wall thickness. The subsequent reversion to normal tracheid diameter is also abrupt, revealing the return of the previous growing conditions. Ground-penetrating Radar analyses confirmed that the Mata Sequence deposits correspond to a river. The identification of growth interruption zones in a Late Triassic wood assemblage in southernmost Brazilian Gondwana (Paleobotanic Garden of the city of Mata, RS) indicates the presence of tropical, temporarily dry climate conditions, characterized by irregular, short-term environmental disturbances to growth. The taphonomic process was related to a river-channel infilling depositional process, under the influence of high-energy flood events that dragged and buried the trees.
\end{abstract}

Keywords: Wood growth patterns, Mata sequence, gymnosperms, Triassic climate, petrified forest.

RESUMO - O objetivo do presente trabalho foi obter assinaturas climáticas por meio da análise de padrões de crescimento em uma associação de lenhos silicificados a fim de retratar os padrões de evolução do paleoclima no Triássico no Gondwana sul-brasileiro durante um intervalo de condições climáticas globais áridas-semiáridas e esclarecer o contexto sedimentar e o processo tafonômico relacionado a preservação da "Floresta Petrificada", preservada na área central do Estado do Rio Grande do Sul. Seções delgadas foram elaboradas a partir de 13 amostras de lenhos permineralizados, sendo os detalhes anatômicos estudados em microscopia óptica sob luz transmitida. A técnica de Penetração do Solo por Radar (Ground Penetrating Radar - GPR) foi utilizada para obter informações sobre as características deposicionais. Os principais resultados foram: ausência de verdadeiros anéis de crescimento nas amostras e todos os espécimes são caracterizados por interrupções de crescimento concêntricas. Os limites das zonas de interrupção são marcados por um declínio abrupto no diâmetro da célula, mas não são acompanhados por uma redução da espessura da parede celular. A reversão subsequente para o diâmetro traqueídeo normal também é abrupta, revelando o retorno das condições de crescimento anteriores. As análises de GPR confirmaram que os depósitos da Sequência Mata correspondem claramente ao preenchimento de canais fluviais. A identificação de zonas de interrupção de crescimento em uma associação de madeira do Triássico Superior no extremo sul do Gondwana brasileiro indica a presença de condições de clima tropical caracterizado por distúrbios ambientais irregulares de curto prazo ao crescimento das plantas, que foram atribuídos principalmente a estresse hídrico temporário. A história tafonômica esteve relacionada a processos de preenchimento de canais fluviais, sob a influência de inundações de alta energia que arrastaram e soterraram as árvores.

Palavras-chave: Zonas de interrupção de crescimento, Sequência Mata, gimnospermas, Triássico, floresta petrificada.

\section{INTRODUCTION}

Silicified fossil woods are common in the Triassic at the southernmost Brazilian Paraná Basin in the State of Rio Grande do Sul (RS). They are usually found as rolled pieces on sedimentary outcrops, though they occur rarely within the sedimentary deposits (Figure 1). The fossil wood record is comprised mainly of conifer-related gymnosperm forms and indicates a mesophytic flora originating during climate changes that took place in global paleogeography where present-day continents formed a single supercontinent, Pangaea, with exposed land extending from about $85^{\circ} \mathrm{N}$ to 


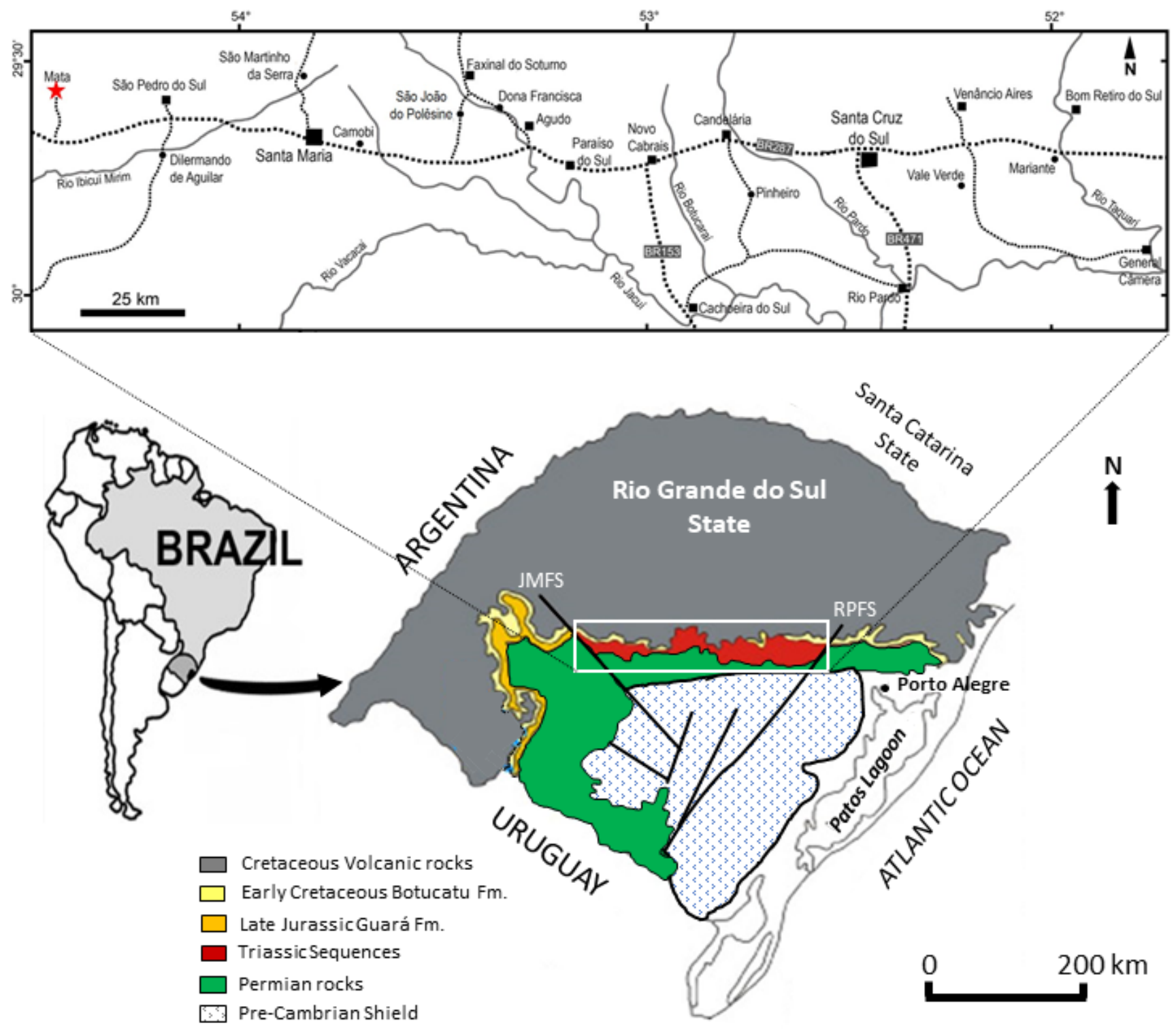

Figure 1. Geographic and stratigraphic positioning of the Triassic sequences in the State of Rio Grande do Sul. The red star indicates the city of Mata, type locality of the Mata Sequence. Abbreviations: JMFS, Jaguari-Mata Fault System; RPFS, Rio Pardo Fault System. Modified from Dentzien-Dias et al. (2007).

$90^{\circ} \mathrm{S}$ (Ziegler et al., 1983) during an interval of climatic conditions linked to a "hot-house" world with ice-free poles (Spalletti et al., 2003; Preto et al., 2010).

The so-called "petrified forests" that flourish in the E-W belt (Central Depression) of the state of Rio Grande do Sul, mainly in the cities of Mata and São Pedro do Sul (Figure 1), are some of the most important paleobotanical sites in South America and are considered part of the region's scientific and cultural heritage.

The petrified woods found in several paleontological sites have been correlated with different Triassic, and potentially Jurassic, stratigraphic units (see Crisafulli et al., 2016, 2018, and citations therein). Different wood taxa have been described for distinct localities (Table 1), consisting mainly of gymnosperm pycnoxylic wood belonging to distinct formtaxa. Nevertheless, while taxonomic analyses have been developed previously and already offer an overview of the floristic diversity, attempts to infer climatic patterns using paleobotanical proxies are still uncommon.

A review of the anatomical studies of wood samples (Table 1) from southernmost Brazil described so far reveals that growth patterns have been identified only briefly and have not been discussed as climatic signatures by the various authors (Minello, 1994; Guerra-Sommer \& Scherer, 2002; Bardola et al., 2009; Crisafulli \& Dutra, 2009; Crisafulli et al., 2016, 2018).

The working hypothesis of this study is based on an assemblage of silicified gymnosperm pycnoxylic wood from sandy layers of the Norian/Rethic Mata Sequence (Horn et al., 2018a, b), preserved within the geographic limits of the Paleobotanic Garden in the city of Mata, that shows anatomical evidence of growth processes (Figures 2 and 3). The main goal of the study was to obtain signatures by analyzing these growth patterns, as they are relevant proxies 
to the predictions of paleoclimate patterns, offering tools for calibration between wood assemblages found in distinct depositional sequences, in order to depict the evolution patterns of the Triassic climate in southern Brazilian Gondwana. Additionally, this study aimed to clarify aspects of the taphonomic process that generated this impressive "Petrified Forest" through stratigraphic analysis coupled with Ground Penetrating Radar.

\section{GEOLOGICAL SYNTHESIS}

\section{Stratigraphic framework}

Since the publication of Huene \& Stahlecker's (1931) work almost a century ago, the sandstone layers containing silicified fossil logs in the central region of Rio Grande do Sul, Brazil, especially in the municipalities of Santa Maria, São Pedro do Sul, and Mata (Figure 1), have been mentioned in the literature. However, the stratigraphic position and age of these fossiliferous levels have been quite controversial ever since.

According to Huene \& Stahlecker (1931), the fossil logs occurred in the same sedimentary layers, the so-called "Rio do Rasto Red Beds," sensu White (1908), that contain tetrapod remains interpreted as Triassic due to the presence of the rhynchosaurus (Scaphonyx Woodward, 1907, Hyperodapedon Huxley, 1859). However, a year earlier, Moraes-Rego (1930) had already recognized that the upper levels of the Rio do Rasto Red Beds (precisely those where Triassic vertebrates and silicified logs occurred) that outcropped in Rio Grande

Table 1. Wood taxa described for the Upper Triassic in southernmost Brazilian Gondwana and indicated growth patterns.

\begin{tabular}{|c|c|c|c|}
\hline Wood Taxa & Location /site & Growth pattern & References \\
\hline Chapmanoxylon jamuriense (Conifera) & Not informed & Growth rings & Crisafulli et al. (2018) \\
\hline Chapmanoxylon sp. cf. C.jamuriense (Conifera) & Rio Soturno & Growth rings absent & Crisafulli et al. (2016) \\
\hline Megaporoxylon kaokense (Conifera) & Rio Soturno & Growth rings & Crisafulli et al. (2016) \\
\hline Agatthoxylon africanum (Conifera) & Rio Soturno & Growth rings & Crisafulli et al. (2016) \\
\hline Labatoxylon kaokense (Conifera) & Not informed & Growth rings & Crisafulli et al. (2018) \\
\hline "Araucarioxylon" spp. (Conifera) & Cerro da Ermida & Growth zones & Minello (1994) \\
\hline Baieroxylon cicatricum (Gingkoaceae) & Chiniquá/Água Boa & Growth zones & Bardola et al. (2009) \\
\hline
\end{tabular}

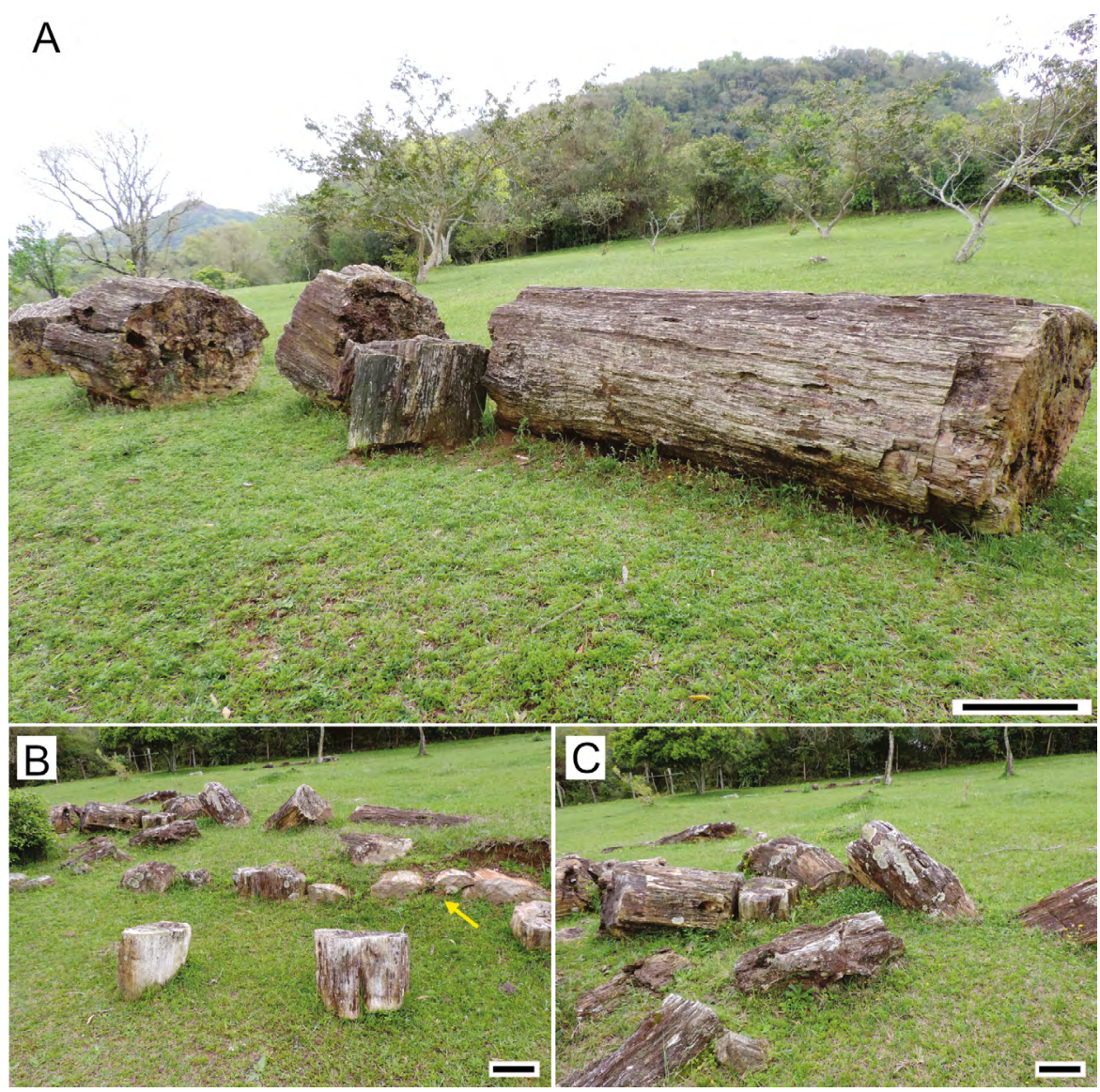

Figure 2. A, general view of the Paleobotanical Garden; B-C, fossil woods of different sizes occur randomly dispersed at ground level and in the subsurface (arrow). Scale bars: $\mathrm{A}=60 \mathrm{~cm} ; \mathrm{B}, \mathrm{C}=30 \mathrm{~cm}$. 
do Sul were distinct from those that occurred in the central and northern portions of Paraná Basin. Moraes-Rego (1930) named these upper levels the Santa Maria Beds (Figure 4). Later, Gordon Jr. (1947) identified a Permian unconformity separating the Santa Maria Beds (Triassic) from the underlying layers, which he called the Rio do Rasto Formation. From his work, the package of red beds containing both vertebrates and silicified logs came to be called the Santa Maria Formation, restricted to Rio Grande do Sul and the Triassic age.

The first author to propose a stratigraphic separation between the red beds containing vertebrate bones and those where the fossil logs occurred was Bortoluzzi (1974),

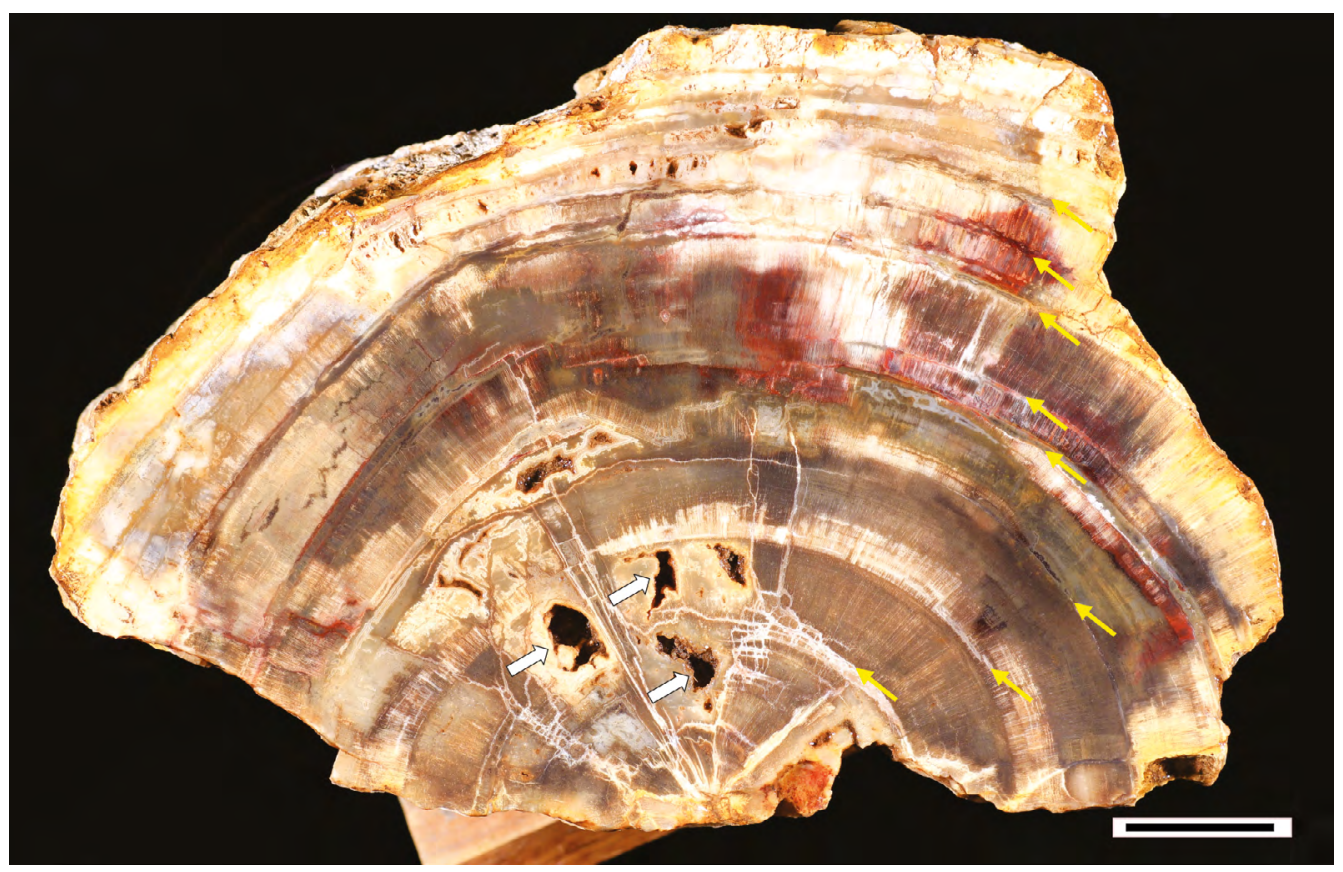

Figure 3. Transversal section showing distinct growth interruptions zones along the wood (yellow arrows) and irregular boring with preferential radial orientation (white arrows). Scale bar $=2 \mathrm{~cm}$.

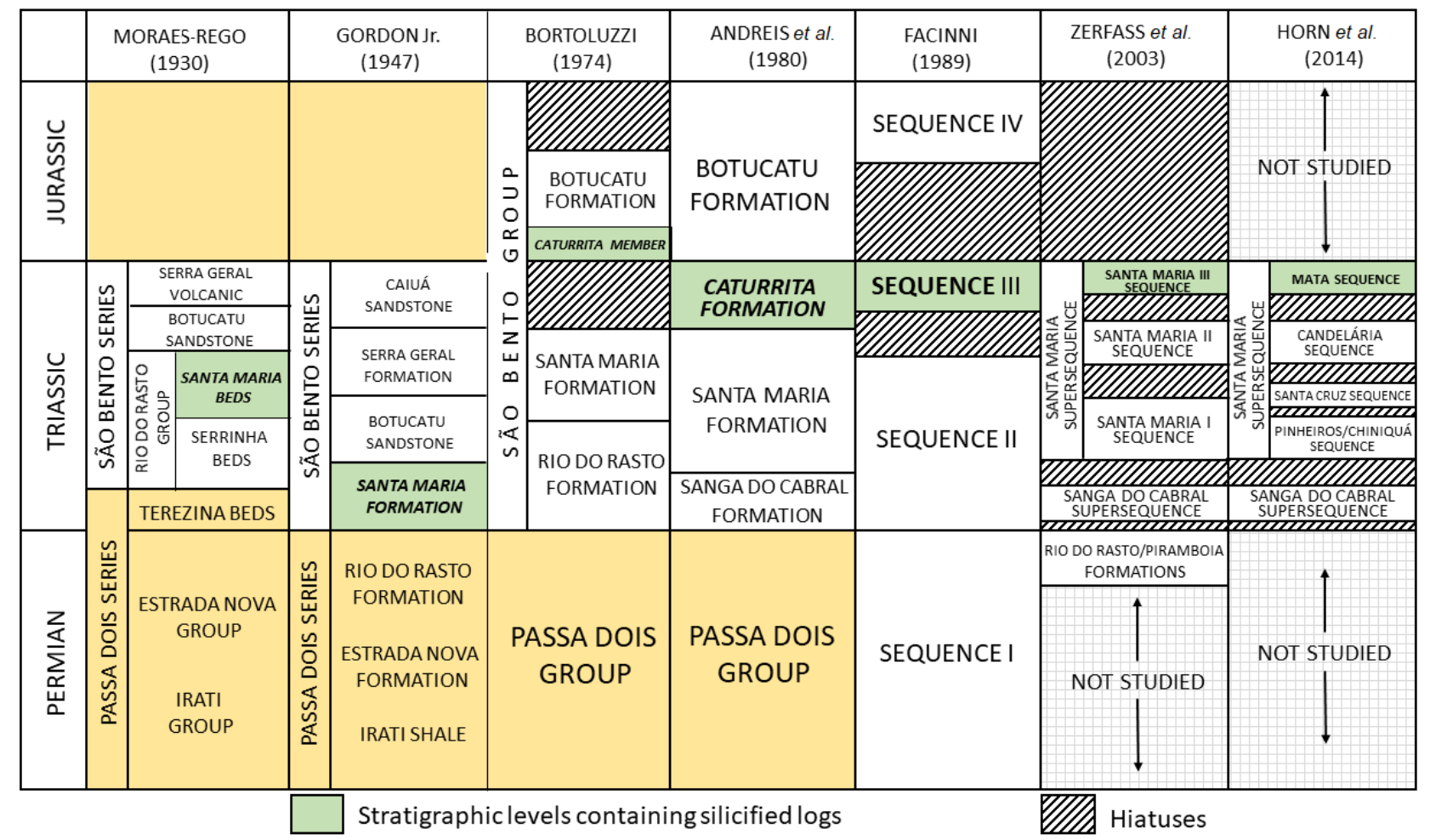

Figure 4. Some lithoestratigraphic and sequence stratigraphic frameworks proposed for the upper Permian-Jurassic package from the State of Rio Grande do Sul including the levels bearing silicified logs. 
who recognized that these two rock packages were separated by an erosive unconformity. Furthermore, for Bortoluzzi (1974), the levels containing the fossil logs (which he called the Caturrita Member) constituted the basal portion of the Jurassic Botucatu Formation, as it was known at the time, the stratigraphic unit that overlays the Santa Maria Formation (Figure 3). Later on, Andreis et al. (1980) proposed the name "Caturrita Formation" to include those layers with fossil logs corresponding to Bortoluzzi's (1974) Caturrita Member as well as others bearing fossil vertebrates (such as rhynchosaurs, cynodonts, dicynodonts and a thecodont) that overlay the Santa Maria Formation further south than those mapped by Bortoluzzi (1974). Based on the fossil vertebrate content of the latter, Andreis et al. (1980) considered the Caturrita Formation Late Triassic in age. This dating was based mainly on the presence of the dicynodont Jachaleria candelariensis Araujo \& Gonzaga, 1980, which would be correlated with the earlier-identified Jachaleria colorata Bonaparte, 1971 that occurred at the base of the Los Colorados Formation in Argentina. The name of the dicynodont from the Caturrita Formation was not mentioned by Andreis et al. (1980) because the paper proposing Jachaleria candelariensis was not yet published at the time.

The first proposal of a stratigraphic framework for the Paraná Basin infilling in Rio Grande do Sul based on sequence stratigraphy was carried out by Faccini (1989), who divided the Upper Permian-Lower Cretaceous package into four depositional sequences, numbered I to IV from bottom to top (Figure 4). In this arrangement, Sequence II (MiddleUpper Triassic) would encompass the entire Santa Maria Formation and the basal layers of the Caturrita Formation, i.e. those containing Jachaleria and other vertebrates (sensu Andreis et al., 1980), while those bearing the fossil logs (corresponding to the Caturrita Member from Bortoluzzi (1974)) corresponded to the Sequence III. In turn, Sequence IV corresponded to the Upper Jurassic-Lower Cretaceous Botucatu Formation.

Subsequently, Milani (1997) performed extensive work throughout the Paraná Basin, proposing a series of secondorder depositional sequences to subdivide the basin's entire filling. Milani (1997) included the rocks corresponding to the Santa Maria and Caturrita Formations (sensu Andreis et al., 1980) in what he called the Gondwana II Supersequence, whose occurrence was restricted to Rio Grande do Sul.

Zerfass et al. (2003) refined part of this framework, focusing on the south Brazilian Triassic package, which they divided into three third-order depositional sequences called Santa Maria I, II, and III, of Ladinian, Carnian and Rhaetian ages, respectively (Figure 4), based on regional unconformities and biostratigraphic dating. The set of these three third-order sequences, in turn, composed a second-order sequence they called the Santa Maria Supersequence, which corresponded to Milani's (1997) Gondwana II Supersequence. In this stratigraphic framework, the Santa Maria I and II Sequences included the layers containing the Triassic vertebrates, while the Santa Maria III Sequence corresponded to the package containing the silicified logs, just as Faccini (1989) had earlier proposed.
Horn et al. (2014) improved the stratigraphic framework established by Zerfass et al. (2003), recognizing a distinct third-order sequence between Santa Maria Sequences I and II and renaming them all (Figure 4). In this new arrangement, the package containing the fossil logs came to be called the Mata Sequence, whose age could be located between the Late Triassic (Rhaetian) and the Late Jurassic. However, it is more likely Triassic due to its fossiliferous content and restricted geographical occurrence, which is limited to the west by the Jaguari-Mata Fault System (JMFS), like the Triassic sequences including vertebrates and unlike the younger units, which extend beyond that line or occur just west of it.

\section{Studied area}

The Paleobotanical Garden outcrop is located within the urban area of the city of Mata (Figures 2, 5 and 6), whose subsoil has revealed the presence of hundreds of silicified logs that are discovered each time an excavation is made for the construction of a street or building. Mata city is the type locality and represents the westernmost point of occurrence of the Mata sequence, which, together with the other Triassic sequences of the Paraná Basin in the extreme south of Brazil, is limited by the JMFS, a great geological alignment with a SE-NW orientation (Figure 1). However, this is not true in the opposite direction, where the Middle and Upper Triassic sequences containing fossil vertebrates extend much further east to the vicinity of the city of General Câmara, where they are limited by another major SW-NE lineament called the Rio Pardo Fault System (RPFS). The last records of the Mata Sequence, in turn, are located to the east in the Agudo region, in the center of the W-E Triassic outcrop belt.

In the studied outcrop, the fossil woods occur dispersed at ground level and in the subsurface within fine to medium pinkish-whitish sandstones with through cross-bedding, often presenting conglomeratic levels with reddish mud clasts at the base.

Four wells (0553-COR-MAT-0, 0557-COR-MAT-021, 0846-COR-MAT-03, and 3027-COR-MAT-04), drilled within the city limits by the state sanitation company (CORSAN$\mathrm{RS}$ ) to assess the aquifer, showed (in all drillings) that the Mata Sequence is covering a thick pack of red muds, which are interbedded with reddish sandstone levels, typically representing one of the older Middle-Upper Triassic sequences that contain the fossil vertebrates. The depth of this contact varies from 6 to $11 \mathrm{~m}$ among the different wells. In the city of São Pedro do Sul, about $60 \mathrm{~km}$ east of Mata, it is possible to see the contact between the Mata Sequence and the underlying red mudstone package at the surface. The presence of the rhynchosaur Hyperodapedon in the red mudstone package indicates that those mudstones represent the lower portion of the Candelária Sequence, whose faunal content characterizes the Hyperodapedon Assemblage Zone (upper Carnian/lower Norian). From this, the erosive and discordant character of the contact between the Candelária and Mata sequences is once again apparent, since the entire upper part of the Candelária Sequence (the Riograndia Assemblage Zone middle-upper Norian) is absent in that region. 


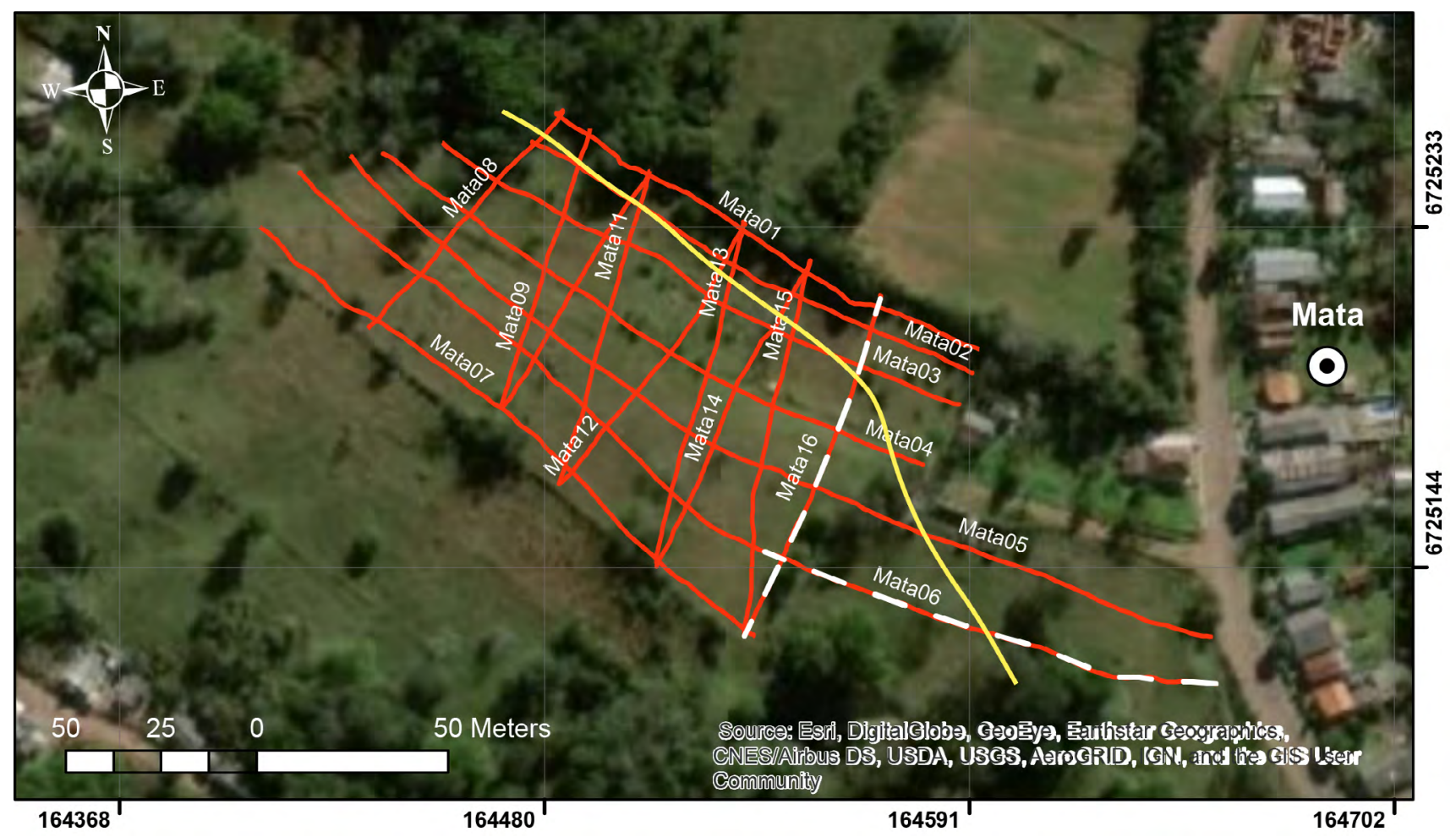

Figure 5. Location map of the GPR sections made at the Paleobotanical Garden in the city of Mata. Red-white lines indicate the selected orthogonal sections (6 and 16). The yellow line indicates the position of the structural height at NE against which the layers of the Mata sequence progradate in onlap.

\section{MATERIAL}

Thirty samples were collected from different areas of the Paleobotanic Garden of Mata, RS, with authorization from the Institute of Historical and Cultural Heritage of the State of Rio Grande do Sul (IPHAE), no. 243/2019/IPHAE. The site has an area of $36,391 \mathrm{~m}^{2}$ and was listed by IPHAE in April 2018 (IPHA013/2018) as a site of cultural importance. It is located in the urban area of the city of Mata $\left(29^{\circ} 32^{\prime} 58^{\prime \prime} \mathrm{S}\right.$, $54^{\circ} 27^{\prime} 32^{\prime \prime} \mathrm{W}$ ).

The wood specimens were preserved by the permineralization process of silica (Dietrich et al., 2013). These large wood pieces with circular diameters ranging from 0.20 to $0.80 \mathrm{~cm}$, are disposed semi-horizontally, randomly dispersed, and frequently semi-included in sediments (Figure 2). The specimens are mostly decorticated, and irregularly bordered cracks are observed in the region of the pith, which is not preserved. There was no recorded occurrence of roots organically associated with these fragments or as isolated fragments. Given the legal restrictions for working in areas protected by IPHAE, fragments of wood were collected in a manner to minimize damage to the great stems exposed in the Paleobotanical Garden.

\section{METHODS OF STUDY}

\section{Ground-Penetrating Radar (GPR)}

The electromagnetic method GPR was used to obtain information on the site's depositional characteristics and to elaborate on its subsurface profile. This technique was previously used by Silva (2009) and Bardola (2011), with good results in Triassic sites of southernmost Brazil, to identify subsurface fossil material. The GPR profiles were acquired using Cobra Plug-In GPR (Radar team Sweden AB) and YUMA 2 (Trimble ${ }^{\circledR}$ ) data acquisition systems with a SUBECHO SE-70 aerial antenna with a central frequency of 80 $\mathrm{MHz}$ and a two-way travel time (TWTT) range of $500 \mathrm{~ns}$. This configuration penetrated $23.5 \mathrm{~m}$ deep. High-pass, stacking, and gain filters were applied during the time of data acquisition. Altitudes were determined by a Global Navigation Satellite System (GNSS) Trimble ${ }^{\circledR}$ ProXRT unit, datum WGS84.

The data was post-processed with Reflex-Win ${ }^{\circledR}, \operatorname{Radan}^{\mathrm{TM}}$, and Prism $2 \circledR$ software packages, followed by trace analysis (Leandro et al., 2019), background removal, band-pass frequency filter (ORMSBY), gain equalization, time to depth conversion, and topography correction. A dielectric constant of 10 fordry sand was used to convert travel time to depth, which represents a velocity of $0.09 \mathrm{~m} / \mathrm{ns}$ (Davis \& Annan, 1989). The stratigraphic interpretation was based on the method of seismic stratigraphy adapted to GPR (Neal, 2004). The method is based on termination (onlap, downlap, toplap, and truncations), geometry, internal configuration, and reflection patterns (Abreu et al., 2010; Barboza et al., 2014).

\section{Anatomical analyses of the woods}

Given the poor preservation of their internal structures, only 13 of the 30 samples collected were analyzed anatomically. The material was prepared according to standard procedures, i.e. with the elaboration of polished blocks and thin sections of the polished three surfaces (transversal, longitudinal radial, 

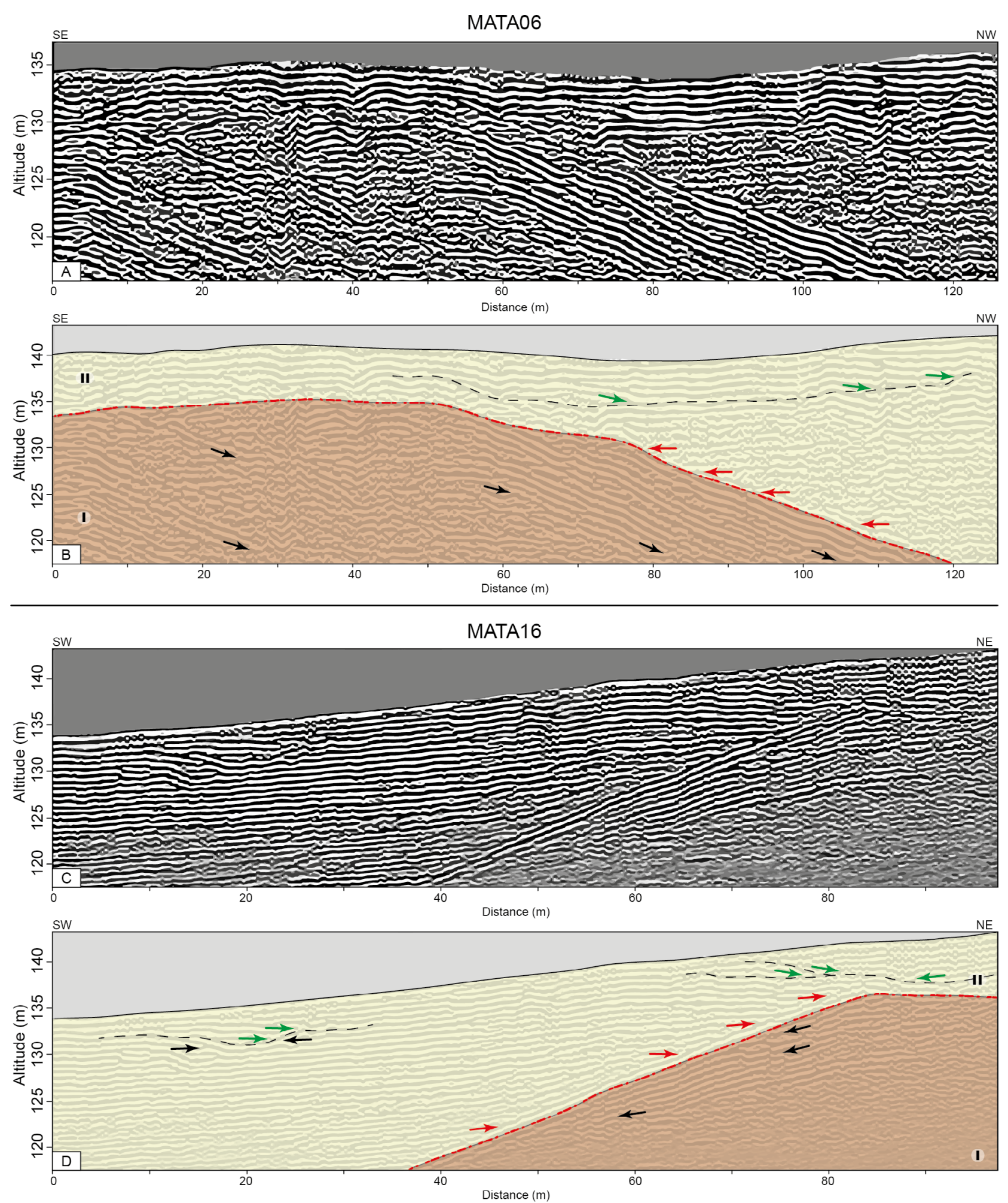

Figure 6. Two selected GPR sections (MATA06 above and MATA16 below) showing the structural relationships between the Mata Sequence (above) and the presumed Candelária Sequence in the subsurface. The arrows show the progradation pattern of the deposition of the Mata Sequence over a structural height at NE, as well as a channel structure (black dashed lines) running parallel to the border of the height (indicated by the yellow line presented in Figure 5).

and longitudinal tangential) mounted in Canada balsam and observed with optical microscopy in transmitted light in a Carl Zeiss MC80 microscope. Photomicrographs were taken using a digital camera (AxioCamMRc) and the software AxioVision $L E$ at the Instituto de Geociências (IG), Departamento de
Paleontologia e Estratigrafia, Universidade Federal do Rio Grande do Sul (UFRGS).

The woods' anatomical patterns were described according to the list of microscopic features for softwood identification (IAWA Committee, 2004). For the identification of wood 
growth patterns and paleoclimate inferences, we consulted Douglass (1928), Creber \& Chaloner (1984), Falcon-Lang (2003), IAWA Committee (2004), and Schweingruber (1992, 1996, 2007).

Macroscopic specimens are housed in the Paleontological Museum of Mata, RS, and petrographic slides are housed under the acronym PB-5496 to 5510 at the Paleobotanical Collection of the Paleontological Museum of the Departamento de Paleontologia e Estratigrafia, IG/UFRGS.

\section{RESULTS}

\section{GPR}

The GPR grid from the locality (Paleobotanical Garden) is excellent, and two representative sections were selected for interpretation, identified as MATA06 and MATA16, respectively. From these samples, we were able to identify a paleochannel and two units, as shown in Figures 5 and 6.

Unit I was identified in a subsurface at the 135 -meter altimetric quota in both sections, and its portion closest to the surface is located in the MATA06 section, between 0 and $50 \mathrm{~m}$, with a NW inclination. Additionally, in the MATA16 section, the altimetric quota was located between 80 and 97 $\mathrm{m}$, showing a reflection dipping to $\mathrm{SW}$.

In both sections, MATA06 and MATA16, Unit I is characterized by high amplitude and continuous, parallel cross reflections with downlap terminations, which indicate that this unit has depositional structures such as large crossstratifications. Unit II presents continuous reflections with high amplitude, with parallel and onlap on the surface that delimits the top of Unit I. In the MATA16 section, erosive truncations are delimited by characteristics, and surface excavations are observed at distances between 10 and $30 \mathrm{~m}$. Downlap reflections are identified on this surface, as well as stratifications, but with lower angles than in the MATA06 section.

\section{Wood analyses}

Given the poor preservation, very few of the fragments exhibit anatomical preservation to provide some taxonomical data and, consequently, formal taxonomic analyses have not been developed. However, despite the poor preservation, two gymnosperm wood xylotypes were recognized mainly based on patterns of radial pitting on the tracheids.

The Xylotype 1 occur in three specimens and exhibited a decorticated pycnoxylic wood with canals and ducts absent. In the longitudinal radial section, the pits on tracheid walls are of the araucarian type, uniseriate, biseriate alternate, and contiguous (Figures 7A-C); cross-field were not preserved (Figure 7C). The anatomical features point to a conifer wood with araucarioid anatomy, showing similarities with Agathoxylon type of wood according to the morphotype criteria of Philippe \& Bamford (2008) for Mesozoic secondary woods. This wood pattern has been included by different authors within the Araucariaceae family (Sagasti et al., 2019 and citations therein). Nevertheless, the non-preservation of crossfield pits precludes the establishment of secure affinities.
The Xylotype 2, showed by 10 specimens, is also a decorticated, homoxylic, and pycnoxylic wood; canals or ducts are absent. Areolate pitting in the tracheid walls presents a dominant uniseriate, isolated disposition (Figures 7D, E), and slight spiral thickening (Figure 7E). Cross-field pits are inconspicuous oculipores seemly irregularly disposed with one or two pits per cross-field (Figures 7D, E) and, in some areas, the end of tracheids radially appears like golf clubs (Figure 7F), suggesting an affinity with Gynkgoacea trees.

Despite the limitations for establishing taxonomic sources of variability within the wood assemblage, given that silicified woods are the unique type of fossil found in the rock packet being studied (the Mata Sequence), we decided to use the woods' growth patterns as indicators of climate.

Of the 30 wood specimens collected from the Paleobotanic Garden in the city of Mata, only 13 specimens had sufficient anatomical preservation to examine their growth patterns. Growth patterns from the wood assemblage are quite unlike true "growth rings" as defined by Greguss (1972), Fritts (1976), Creber \& Chaloner (1984), and Schweingruber (1992, 1996), which are produced by a complete cessation of cambial activity and appear continuously around the trunk circumference, displaying well-marked, asymmetrical ring boundaries defined by numerous latewood cells with cell wall thickening.

Instead, the wood growth patterns present in our specimens were identified as "growth interruptions", as defined by Schweingruber (1992), which result from a temporary slowing down of cambial activity and are different in origin from true growth rings (Figures 3, 8, 9).

The observation of continuous sequences was highly impaired in our material given the irregular preservation of single specimens caused by distinct silicification processes along with the samples, characterized in some levels by the occurrence of large silica crystals that were associated with randomly dispersed elongated cracks (Figure 3), cellular crushing, and, in some cases, extreme wood deformation processes. Cell-by-cell measurements in cross-sections of adjacent rows detected distinct growth zone boundaries, which were informally identified as morphologic types according to some of the criteria established by Falcon-Lang (2003). However, it was difficult to draw clear boundaries between the two types because some wood displayed a great variation in patterns within a single specimen.

The interruption Zone Type I is inconspicuous and subtle and is only represented in some punctual sections of the wood. Its boundaries cannot be traced laterally and these zones are absent for a considerable distance within the horizontal sections. They are distinguished by a sudden decline in cell diameter followed by a rapid rise back to the tracheid diameter compatible with wood-tracheids of analogous earlywood (Figure 8). In each zone, the tracheids equivalent to the initial wood have radial diameters ranging from 39 to $57 \mu \mathrm{m}$ (mean $47.7 \mu \mathrm{m}$ ) and walls from 5 to $8.5 \mu \mathrm{m}$ (mean $6.6 \mu \mathrm{m}$ ) thick. In the analogous latewood, 3 to 5(7) rows of tracheids are flattened with radial diameters of 21 to $35 \mu \mathrm{m}$ (mean 29.7 $\mu \mathrm{m}$ ) and walls from 5.2 to $9.0 \mu \mathrm{m}$ (mean $8 \mu \mathrm{m}$ ) thick. The tracheids that mark the interruptions do not have thickened cell walls in relation to the earlywood tracheids (Figures 8A, B). 

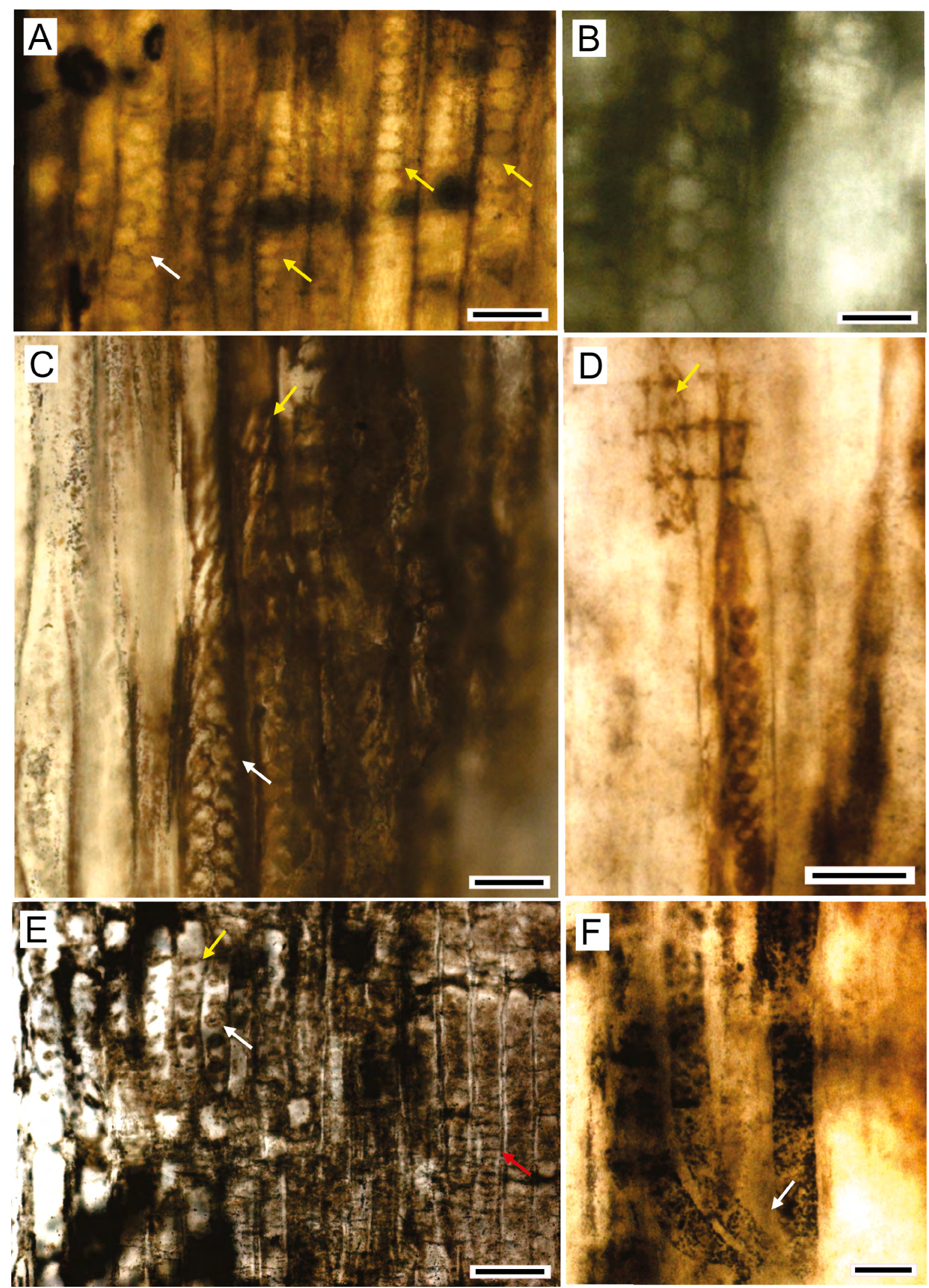

Figure 7. Wood radial sections. Xylotype 1: A, tracheid walls showing bordered piting, with araucarian disposition from contiguous uniseriate (yellow arrow), to alternate biseriate (white arrow). B, detail of a biseriate, alternate, polygonal-shaped areolate pitting on tracheid walls. C, cross-field pits poorly preserved (white arrow) and biseriate pits (yellow arrow). Xylotype 2: D, uniseriate isolated to areolate pitting in the tracheid walls associated with spiral thickening and cross-field pits showing two pits per cross-field (yellow arrow). E, uniseriate isolated areolate pitting in the tracheid walls spiral thickening (red arrow); cross-field pits inconspicuous (yellow arrow). $\mathbf{F}$, terminalization of tracheids resembling golf clubs (white arrow). Scale bars: $\mathrm{A}, \mathrm{C}, \mathrm{D}, \mathrm{F}=50 \mu \mathrm{m} ; \mathrm{B}=25$ $\mu \mathrm{m} ; \mathrm{E}=100 \mu \mathrm{m}$. 

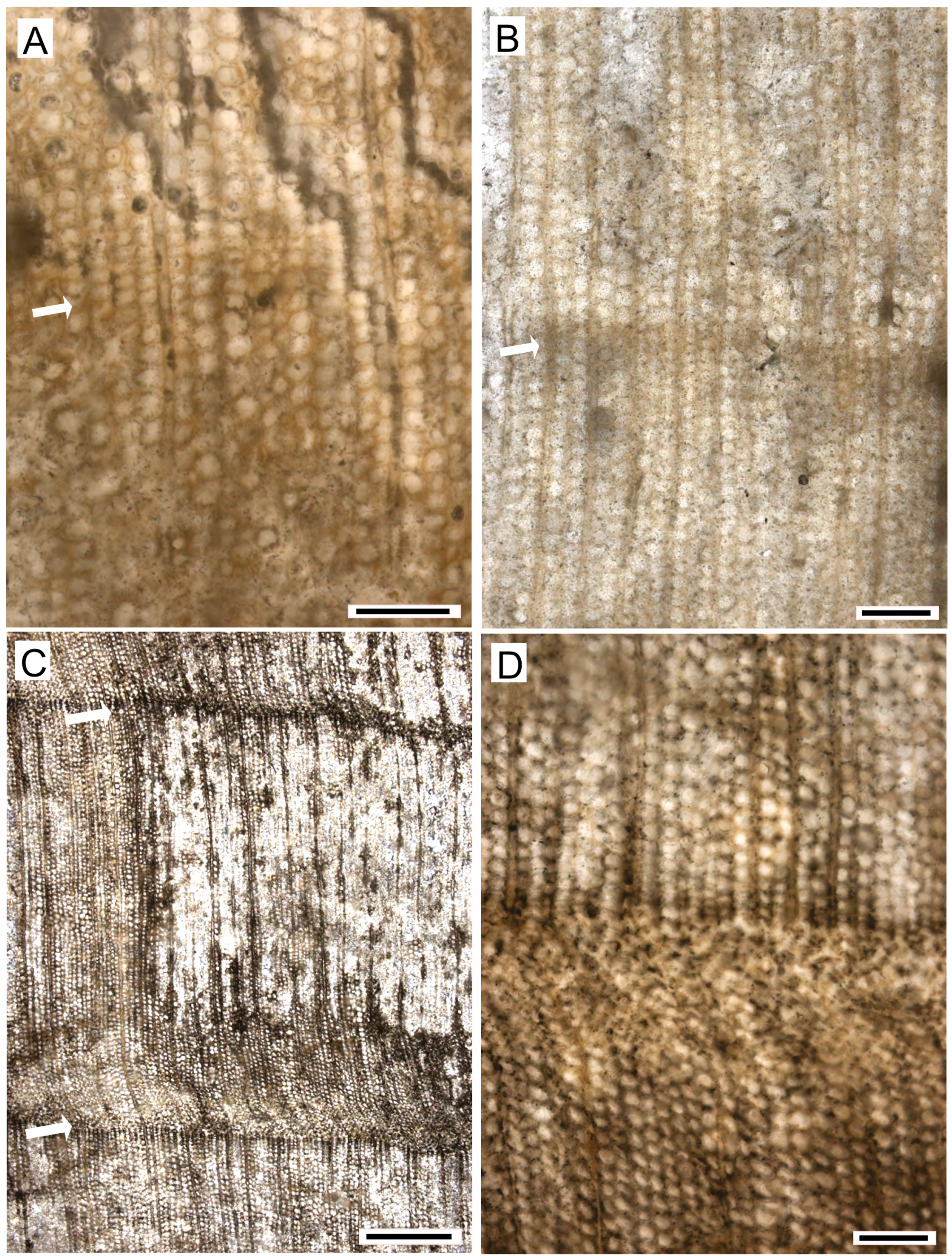

Figure 8. Growth interruption types (indicated by the arrows). A, growth interruption locally almost absent. B, typical weakly interruption boundaries which cannot be traced laterally. C, marked interruption traced laterally along cross-section. $\mathbf{D}$, zone boundaries marked by an abrupt decline in cell diameter and subsequent abrupt reversion to normal tracheids diameter. Scale bars: A, B, D $=200 \mu \mathrm{m}, \mathrm{C}=1000 \mu \mathrm{m}$. 

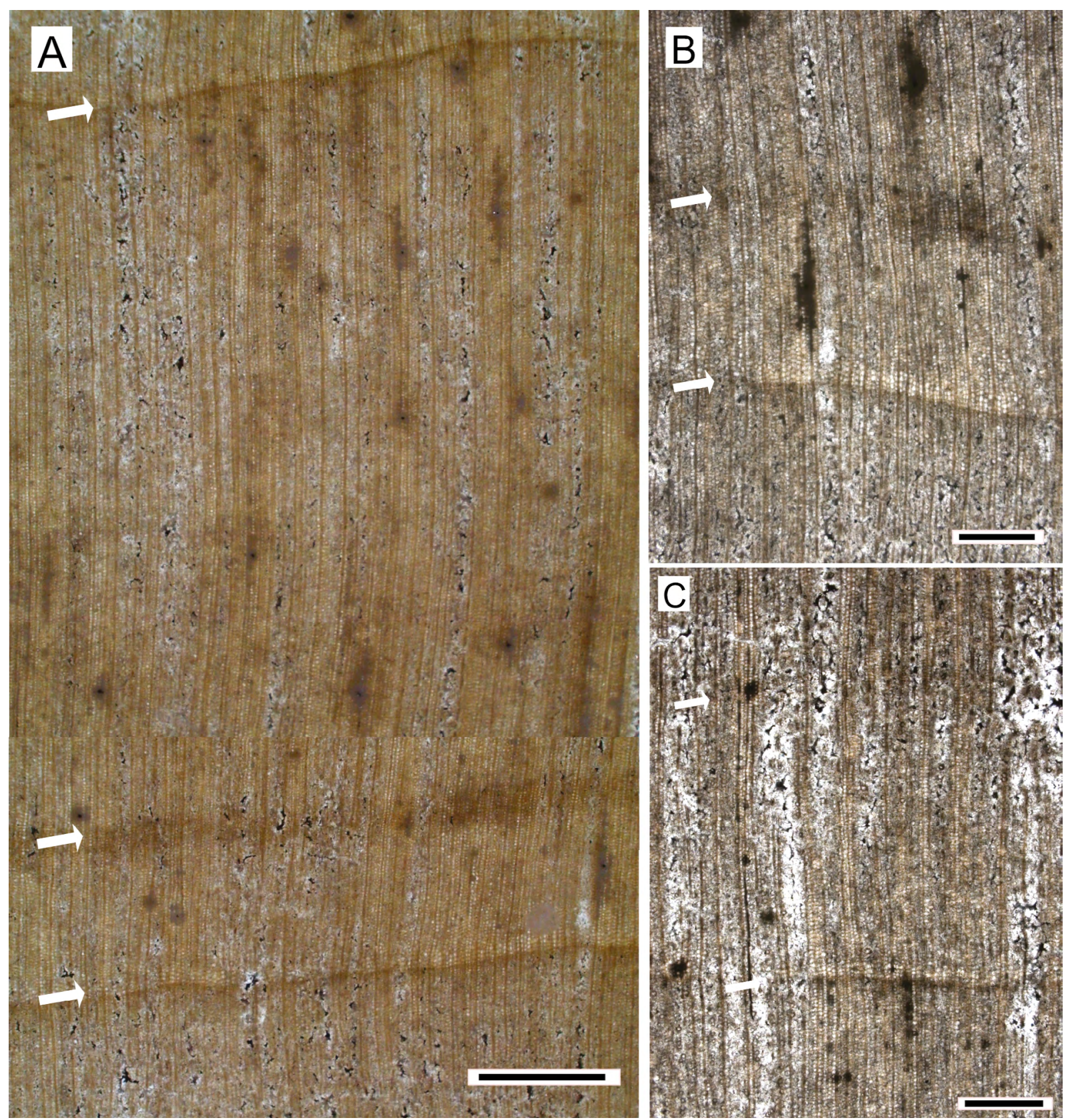

Figure 9. The spacing of wood growth interruption (indicated by the arrows). A, general view boundary spacing from marked growth interruptions in a single specimen. B, marked growth interruptions interspersed with very weakly ones in a single specimen. $\mathbf{C}$, inconspicuous boundary spacing between two weakly zones. Scale bars: $\mathrm{A}=2 \mathrm{~mm} ; \mathrm{B}, \mathrm{C}=1 \mathrm{~mm}$.

Given the inconspicuous nature of these zones, it was not possible to describe the ring boundary spacing.

Type II is dominant and characterized by marked growth boundaries which are observable continuously along with the thin slides (Figure 8) and in polished cross-sections (Figure 3). The tracheids equivalent to the initial wood have radial diameters of 39 to $65 \mu \mathrm{m}$ (mean $52.9 \mu \mathrm{m}$ ) and walls from 5 to $8.5 \mu \mathrm{m}$ (mean $6.6 \mu \mathrm{m}$ ) thick. In the analogous latewood, two to three rows of tracheids are flattened with radial diameters between 24.7 and $35 \mu \mathrm{m}$ (mean $29.7 \mu \mathrm{m}$ ) and walls between 5.2 and $9.0 \mu \mathrm{m}$ (mean $8 \mu \mathrm{m}$ ) thick. Similar to those found in Type I, the tracheids that mark the interruptions in Type II do not have thickened cell walls in relation to the earlywood tracheids. Their boundaries are marked by an abrupt decline in cell diameter, and the subsequent reversion to normal tracheid diameter is equally abrupt (Figures 8C, D). The growth interruptions in the wood fragments are constant but irregularly spaced (Figure 9A), and individual growth zones are spaced between 1 and $9 \mathrm{~mm}$ apart (mean $4.5 \mathrm{~mm}$ ). Additionally, distinct types of boundary patterns can be recognized throughout the same cross-section of a single specimen. It was then possible to observe along the secondary xylem the occurrence of well-demarcated growth interruptions interspersed with very weakly developed growth interruptions (Figures 9B, C). 
In an attempt to make greater contributions to climatic inferences, mean sensitivity statistical analysis was applied unconventionally to the growth interruption sequences, since its application by Falcon-Lang (2003) yielded good results in spacing variability using Fritts' (1976) equation:

$$
\mathrm{MS}=\frac{1}{n-1} \sum_{t=1}^{t=n-1}\left|\frac{2\left(x_{t+1}-x_{t}\right)}{x_{t+1}+x_{t}}\right|
$$

where $x$ is the distance between adjacent growth interruptions, $n$ is the number of growth increments in the analyzed sequence, and $t$ is the year number of each increment.

The statistical analysis of 13 wood fragments, obtained from the 70 growth zones (measured in polished blocks and confirmed under the transmitted light microscope) spaced between 1 and $13 \mathrm{~mm}$ apart (mean $5.9 \mathrm{~mm}$ in total), showed mean sensitivity values of 0.221 to 1.225 (mean of 0.687 ) (Table 2).

According to Fritts (1976), average sensitivities greater than 0.3 (MSR > 0.3) indicate that the woods were sensitive to fluctuating climate parameters.

\section{Deformation of wood structures}

In all samples, the anatomical structures of the secondary wood show distinct patterns of anomalies and were often deformed, crushed, and sometimes extensively distorted. Wide and continuous undulations along the secondary wood are present in some specimens, however, they do not significantly alter the tracheid and rays morphology (Figure 10A).

Several specimens displayed laterally interconnected cracks produced by a few levels of collapsed tracheid rows, interspersed in rows of non-compressed cells, sometimes giving these samples the appearance of false rings (Figure 10B).

The dominant wood deformation anomaly throughout the entire assemblage is a strong zigzag, chevron-like pattern, caused by strong compression of the tracheids (Figure 10C). Frequently, individual tracheids are highly tangentially compressed, and cells are sinuous in the transverse section, seemingly having gelatinous walls (Figure 10D).

\section{Evidence of wood decay}

In the transverse and longitudinal sections, the secondary xylem in several specimens shows irregular cavities $(2.2$ to
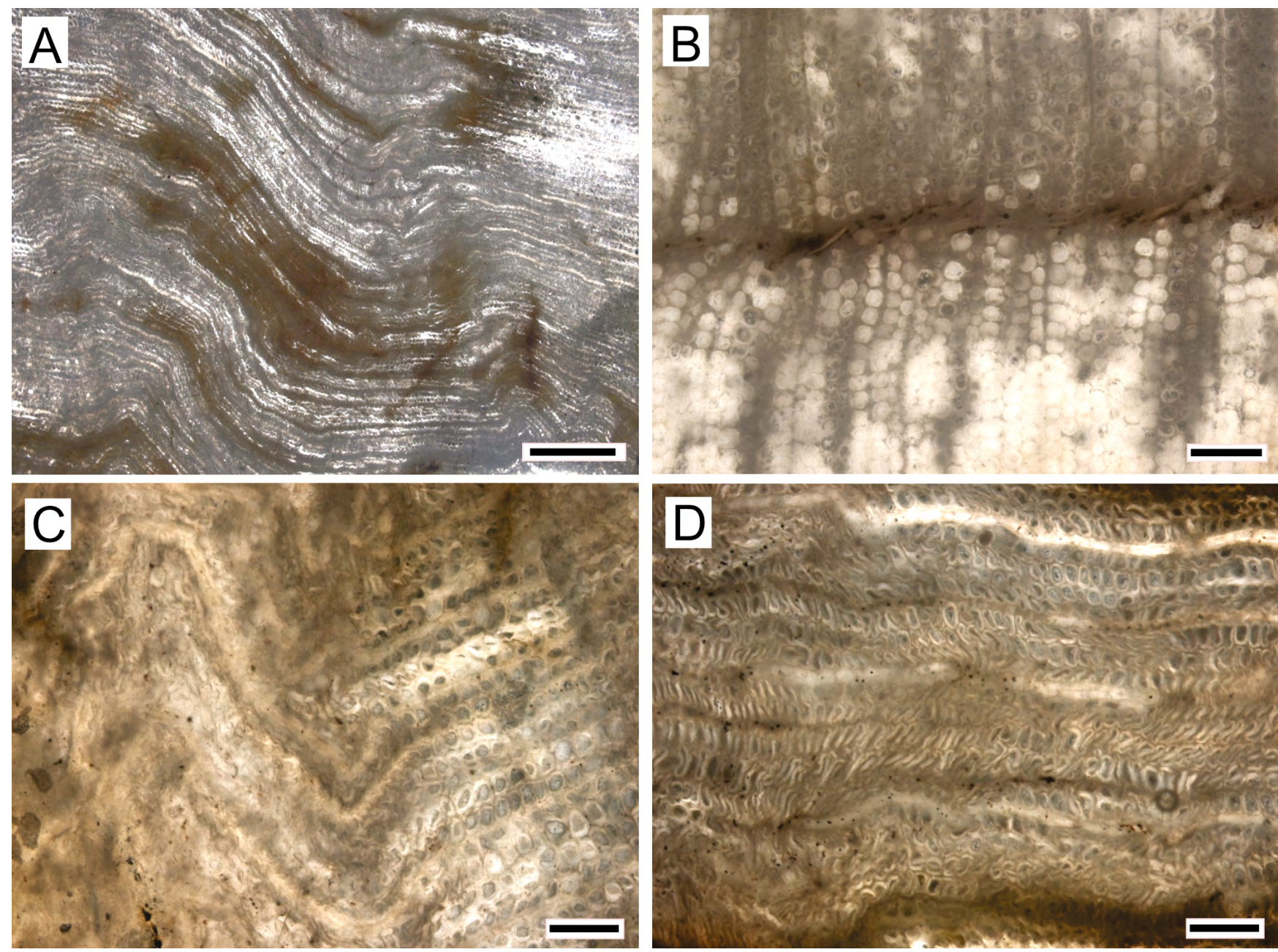

Figure 10. Deformation wood structures in cross-section. A, wide and continuous undulations along the wood tissue. B, abrupt linear compression along few rows of tracheids. $\mathbf{C}$, strong zigzag, chevron-like pattern, elongated parenchyma cells of the rays curved but not broken. D, very compressed cells showing sinuous cell-walls. Scale bars: A $=1000 \mu \mathrm{m} ; \mathrm{B}, \mathrm{C}, \mathrm{D}=200 \mu \mathrm{m}$. 
$3.1 \mathrm{~mm}$, average $2.7 \mathrm{~mm} \times 0.8$ to $2.5 \mathrm{~mm}$, average $1.6 \mathrm{~mm}$ ) of different sizes randomly distributed throughout it (Figures $11 \mathrm{~A}, \mathrm{~B})$. Furthermore, the walls of the tracheids that bordered the borings have been gnawed, and the frass is composed of discernible plant material, mainly degraded tracheid wall fragments (Figure 11C) and, rarely, isolated, non-clustered bodies, typically dark in colour, with a fairly regular circular to oval outline, ranging from 297 to $303 \mu \mathrm{m}$ in length and 141 to $207 \mu \mathrm{m}$ in width (Figure 11D). These bodies were identified as arthropod coprolites because of their similarities with faecal pellets produced by living phytophagous arthropods (Snyder, 1924).

Tracheids filled with dark contents clustered as massive bands were observed, which are typically associated with boring (Figures 11B, C) and likely document host cell reactions to fungal attacks in fossil woods (Aist, 1976; Pujana et al., 2009; Gnaedinger et al., 2015), similar to the reaction seen in extant woods (Blanchette, 1990; Schwarze, 2007).
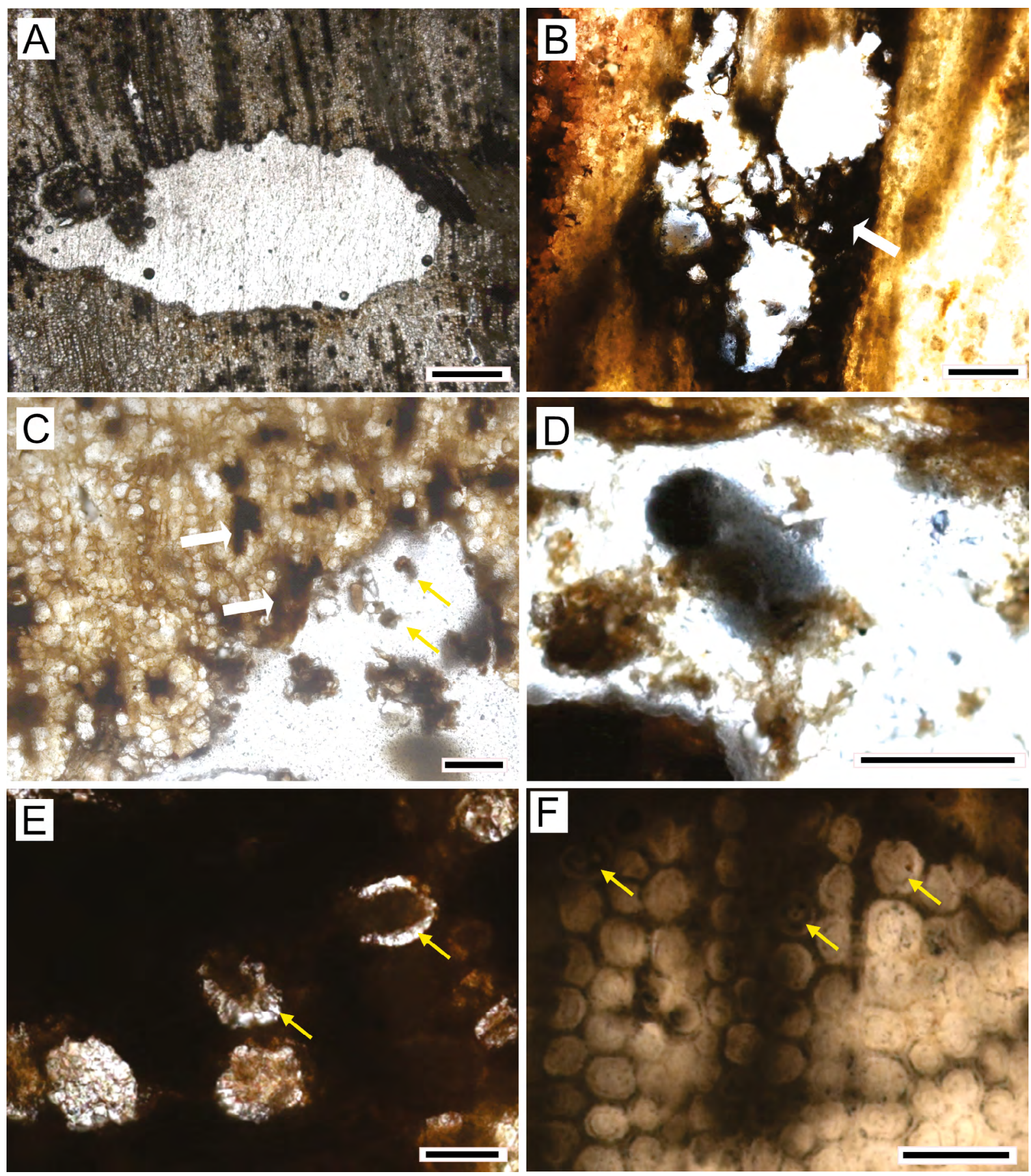

Figure 11. Evidence of wood decay. A, transverse view of a boring. B, longitudinal view of different borings with irregular borders, encircled by dark bands (white arrow). C, irregular borders of the boring, encircled by dark tracheid bands (white arrow) and frass inside the lumen (yellow arrow). D, coprolite. E, fungal spores included in tracheid lumina (yellow arrow). F, transverse circular section of elongated hyphae bordering walls, inside cellular lumen (yellow arrow). Scale bars: $\mathrm{A}=1000 \mu \mathrm{m} ; \mathrm{B}, \mathrm{C}, \mathrm{D}=200 \mu \mathrm{m} ; \mathrm{E}=50 \mu \mathrm{m} ; \mathrm{F}=100 \mu \mathrm{m}$. 
Table 2. Results of growth interruptions analysis.

\begin{tabular}{|c|c|c|c|c|c|c|c|c|}
\hline & Samples & $\begin{array}{l}\text { Number of } \\
\text { growth rings }\end{array}$ & $\begin{array}{l}\text { Minimum ring } \\
\text { width (mm) }\end{array}$ & $\begin{array}{l}\text { Maximum ring } \\
\text { width }(\mathrm{mm})\end{array}$ & $\begin{array}{l}\text { Mean ring width } \\
(\mathrm{mm})\end{array}$ & $\begin{array}{c}\text { Mean sensitivity } \\
\text { MS }\end{array}$ & $\begin{array}{l}\text { Minimum annual } \\
\text { sensitivity }\end{array}$ & $\begin{array}{l}\text { Maximum annual } \\
\text { sensitivity }\end{array}$ \\
\hline 1 & PB 03 & 7 & 1 & 5 & 2.7 & 0.654 & 0 & 1.333 \\
\hline 2 & PB 05 & 4 & 2 & 6 & 4.3 & 0.693 & 0.222 & 1.000 \\
\hline 3 & PB 09 & 5 & 2 & 11 & 6.8 & 1.073 & 0.588 & 1.385 \\
\hline 4 & PB 13 & 2 & 5 & 11 & 8 & 0.75 & 0.750 & 0.750 \\
\hline 5 & PB 14 & 4 & 3 & 13 & 8 & 0.765 & 0.476 & 0.909 \\
\hline 6 & PB 15 & 6 & 3 & 11 & 5.2 & 0.515 & 0 & 1.143 \\
\hline 7 & PB 17 & 13 & 2 & 6 & 3.9 & 0.285 & 0 & 1.000 \\
\hline 8 & PB 18 & 7 & 2 & 13 & 7 & 1.125 & 0.933 & 1.385 \\
\hline 9 & PB 19 & 2 & 6 & 9 & 7.5 & 0.4 & 0.400 & 0.400 \\
\hline 10 & PB 20 & 4 & 3 & 9 & 6.3 & 0.468 & 0.154 & 1.000 \\
\hline 11 & PB 21 & 5 & 1 & 11 & 4.6 & 0.968 & 0.222 & 1.333 \\
\hline 12 & PB 22 & 5 & 2 & 13 & 6.2 & 1.011 & 0.666 & 1.467 \\
\hline \multirow[t]{2}{*}{13} & PB 23 & 6 & 4 & 9 & 6.2 & 0.221 & 0 & 0.545 \\
\hline & Total & 70 & & Mean & 5.9 & 0.687 & & \\
\hline
\end{tabular}

Fungal bodies corresponding probably to spores (Figure 11E) and hyphae (Figure 11F) were found growing inside tracheid lumina along the secondary xylem. Nevertheless, poor preservation hampered diagnostic affinities for this fungal remains.

\section{DISCUSSION}

The GPR sections, described previously, were interpreted on-site (Figures 5 and 6) and indicated that the Mata Sequence is onlapping another sedimentary unit that configures a structural high in the subsurface located northeast of the outcrop, which is characteristic of an erosive discordant contact. Additionally, GPR section MATA16 (Figures 6C, D) shows a clear channel structure running parallel to this high, whose orientation is consistent with the preferred orientation of the outcropping trunks, which are perpendicular to the channel identified in the GPR section. This confirms that Mata Sequence deposits clearly correspond to river channel infilling, and the logs must have been dragged into these channels during flood events.

Conventionally, the Triassic has been considered a "hot-house warm equable" world, with no major climate oscillations or trends, and was seemingly arid to semi-arid in interior Gondwana during the Middle to Late Triassic (Sellwood \& Valdes, 2006). In agreement with the general global scale context, a general semi-arid climate for the deposition of the Santa Maria Supersequence was accepted based on chemical indices of alteration (Horn et al., 2018a, b). However, despite the chemical indices, results based on field, chemical, and fossil vertebrates data suggest a climate marked by great seasonal changes during the deposition of the Middle/ Upper Triassic sequences of the Santa Maria Supersequense (Horn et al., 2018a, b). Results for the Candelaria Sequence (Carnian/Norian), which underlies the Mata Sequence (Rhaetian) in the stratigraphic framework of Horn et al. (2018a, b), indicate a strongly seasonal, semi-arid climate with seasonal rainfall. Nevertheless, several indicators such as a change in depositional systems (eolian/fluvial to fluvial-deltaic sheet deltas in lacustrine environments), climate-sensitive sediments, and faunal change point to an increase in humidity from the upper part of the sequence (Global Carnian Wet Interval). However, the presence of calcrete at the topmost levels suggests a return to semi-arid/arid conditions.

According to Zerfass et al. (2003), facies data to define the depositional processes linked to fluvial style for the Mata sequence (then called the Santa Maria III Sequence) were inconclusive due to the small number of exposures. However, the lack of floodplain facies and the coarse-grained nature of the sandstone suggested high-energy flows to Zerfass et al. (2003). The stratigraphic analyses developed in the present study confirm that Mata Sequence deposits cleary correspond to river channel infilling processes associated with highenergy flows.

A change to fluvial depositional systems during the deposition of the Mata Sequence, as accepted by Horn et al. (2018b), would certainly lead to the establishment of climatic trends somewhat different from those of the lower units. Nevertheless, climatic signatures data that should be provided by fossil woods (the unique fossils preserved in the Mata Sequence) have not been discussed. Growth rings or growth zones (Table 1) are only documented for single specimens and are not accompanied by climatic inferences (Minello,1994; Guerra-Sommer \& Scherer, 2002; Bardola et al., 2009; Crisafulli et al., 2016; Crisafulli et al., 2018), and many of these structures were likely the consequence of taphonomic processes rather than caused by wood growth patterns.

The absence of true growth rings in the wood assemblage preserved in the Paleobotanical Garden locality, included in the Mata Sequence (Horn et al., 2018a, b), point to climatic conditions with minimal year-round variability. Nevertheless, the common occurrence of wood growth interruption interspersed with relatively long cycles of homogeneous 
growth in all sampling (Figure 3) indicates frequent shortterm environmental disturbances to growth that have mainly been attributed to droughts (Fritts, 1976; Schweingruber, 1992, 1996).

The large diameter of the tracheids that commonly follow the growth interruptions was linked with a rapid return to good growing conditions at the end of disturbance events and a consequent increase in water availability. While irregular spacing of growth interruptions implies irregular periods of drought, the interspersed occurrence of marked growth interruptions with tenuous ones in a single wood sample reflects the different intensities of these stress events throughout the life of the plant.

The growth pattern is distinct from that formed under monsoonal conditions, even taking into account the inferences of several authors (e.g. Robinson, 1973; Wang, 2009) who considered this interval to be marked by a maximum expression of a monsoonal climate. As observed by Horn et al. (2018a), reconstructions of the paleolatitudes for South America placed the Santa Maria Supersequence in higher southern latitudes (over $30^{\circ} \mathrm{S}$ ) than would be expected for a monsoonal influence.

Mean sensibility data ratified the results from a cell by cell analysis and, according to Fritts' criteria (1976), the paleoenvironment where these gymnosperms developed was not uniform and included short-term aperiodic disturbances, which caused irregular growth rates, and had variable water supply conditions throughout the life of the plant. The common occurrence of growth interruptions in almost all of the wood samples did not necessarily represent annual increments of growth and was in response to climatic stress caused by erratic rainfall.

The absence of anatomical evidences (e.g. rounded tracheids with intercellular spaces in the latewood) which are typical answers to flooding events, means that drought, not flooding, caused this growth interruption during the tree's life. The general characteristics of the growing pattern point to an ecological niche related to inter-channel environments that were relatively far from meso-hygrophilous sites.

Biological interactions present in several specimens indicate that wood damage is probably attributable to arthropod bores and fungal decay, and involved pathogenic and saprophytic processes. Given that wood-boring arthropods generally attack trees that are already suffering from moisture or other physical or biotic stresses (Bonello et al., 2006; Drees et al., 2006), they were likely secondary invaders during drought intervals under stressful environmental conditions.

Statistical analyses by Pires et al. (2005) in a wood assemblage with Taxaceae affinity from the Faxinal do Soturno outcrop, included by Zerfass et al. (2003) in the Triassic Santa Maria III, is a unique study that allowed for more reliable paleoclimate information. Unlike the present study, Pires et al. (2005) found true growth rings in their sample, indicating periodic growth related to clear seasonal cycles under temperate climatic conditions. Nevertheless, the distinct growth pattern shown in the studied assemblage reflects not only a paleoecological distinction but a distinct age interval, given that an Early Jurassic age for the Faxinal do Soturno outcrop has been strongly suggested based on paleontological and sedimentological data (Barboni \& Dutra, 2013; Rohn et al., 2014; Soares et al., 2014; Jenisch et al., 2017).

Considering the general context of semi-arid conditions for the Middle/Late Triassic of the southernmost Brazilian Gondwana, which indicates seasonal variations between long periods of drought and short, but intense, flood events (Horn et al., 2018a), wood growth patterns from the Mata Sequence (Rhaetian) indicate a relative increase in water availability intervals interspersed with very short, irregular drought intervals.

The aperiodic high-energy flow events did not cause the anatomical responses in the wood during the life span of the trees but, instead, were closely related to their preservation process. The interpretation of GPR analyses, coupled with stratigraphic data, was vital to clarifying the taphonomic process involved in this petrified wood assemblage, which was closely associated with the drag and burial of trees by very high-energy flood events under fluvial environments with a high sediment load.

Additionally, the environmental indicator value of the intense wood deformation, represented by a strong zigzag, chevron-like pattern found in all samples (Figure 10), is linked to their compression by a heavy layer of high-energy flows of channel infilling sediments before the wood was permineralized during the burial process. Based on their morphologies, these anomalous features could not be linked to reactions during the life span of the trees (e.g. reaction wood, frost rings, density fluctuations, and scars) caused by climatic/environmental anomalies such as extreme weather, avalanches, landslides, storms and erosion, fire, mechanical damages, parasites, or lack of light and water (Baas \& Shweingruber, 1987; Shweingruber, 2007; Butler \& Sawyer, 2008; Gärtner \& Heinrich, 2013). These structures are present in Holocene and Pleistocene conifers that ended up in glacial sediments that were later covered by ice and were under high pressure, which caused the wood cells to collapse (Schweigruber, 2007). Such structures were also noticed by Gnaedinger \& Zavatiieri (2020) in coniferous woods from the Upper Triassic of southwestern Gondwana and the Triassic of Antarctica (Del Fueyo et al., 1995) and were attributed to wood compression caused by burial before the permineralization process.

A review of the general tree growth pattern of coeval Upper Triassic assemblages in South America at relatively higher latitudes $\left(45^{\circ} \mathrm{S}\right)$ indicated distinct growth conditions. Wood analyses in the Tronquimalal Group (Neuquén Basin, Mendoza Province) led Gnaedinger \& Zavattieri (2020) to identify a wood growth pattern composed of continuous true growth rings with well-marked ring boundaries defined by numerous latewood cells showing radial thickening of the walls. This evidence, along with other paleobotanical data, indicated a seasonal temperate-warm and humid to sub-humid climate for the western margin of the continent.

Closer comparisons with the Upper Triassic of Antarctica are hampered due to the absence of fossil woods described for this interval. However, true growth rings were identified in wood specimens from the Middle Triassic Fremouw Peak 
(Ryberg \& Taylor, 2007), attributed to a rapid transition to dormancy under the strong influence of the annual light/ dark cycle within the Antarctic Circle. However, some environmental stresses in the polar region were indicated by epicormic shoots and traumatic growth zones in some woods (Decombeix et al., 2018).

The only fossil records in the Upper Triassic that show similarities with our material are those found in conifer woods of the Northern Hemisphere in the Upper Triassic Chinle Formation of Arizona (USA), $15^{\circ}$ north of the paleoequator near the west coast of Pangaea. Those wood assemblages showed no true growth rings and instead displayed irregular growth interruptions that were attributed to periods of drought in a tropical climate (Ash \& Creber, 1990, 1992).

Given the evidence, the growth pattern found in the studied assemblage points to climatic conditions more consistent with tropical/subtropical climatic belts rather than with warm temperate zones. Similar wood patterns have been described for extant subtropical and tropical conifer woods (Schweingruber, 1992).

The exclusive occurrence of gymnosperms with a nonpteridospermophyta affinity during the deposition of the Mata sandstone, attributed to the latest Triassic (Rhaetian), seems to indicate the development of a forest where the corystosperms disappeared, suggesting a temporal change in the plant composition in communities of the long-lasting endemic Triassic Dicroidium-dominated floras. Zhang \& Grant-Mackie (2001) considered the replacement of Dicroidium-dominant floras by conifer forests in the Gondwanan southern hemisphere to be a gradual affair associated with increased humidity, in contrast with the dramatic climate changes attributed to hothouse conditions evidenced by data from northwestern Europe.

\section{CONCLUSIONS}

The report of growth interruption zones in a Late Triassic wood assemblage from fluvial depositional environments in southernmost Brazilian Gondwana (Paleobotanic Garden of the city of Mata, RS) indicates the presence of tropical climate conditions under the influence of a variable and irregular water supply.

These irregular, short-term environmental growth disturbances were attributed to drought fluctuation, which caused temporary water stress and probably influenced the water table. Nevertheless, the return to suitable growing conditions and increased water availability at the end of temporary stress conditions was rapid.

The wood anatomical proxies from the Mata Sequence (Rhaetian) indicate a relative increase in water availability intervals and irregular short-term drought periods, suggesting some climatic change in relation to the conditions in the underlying unit Candelaria Sequence (Carnian/Norian), which was subject to seasonal variations characterized by long dry periods and short, but intense, flood events.

Stratigraphic analysis coupled with GPR ratified the riverchannel infilling depositional process for the Mata Sequence and clarified some stages of the taphonomic process of the wood assemblage, which occurred under the influence of high-energy flood events that dragged and buried the trees originally adapted to ecological niches linked to inter-channel environments.

\section{ACKNOWLEDGMENTS}

A.M.S., M.G.S., and C.L.S. acknowledge the financial support of CNPq (Conselho Nacional de Desenvolvimento Científico e Tecnológico). The authors are also grateful to IPHAE (Instituto do Patrimônio Histórico e Artístico do Estado) for permitting us to conduct research in the Paleobotanic Garden and to the municipal government of Mata for their collaboration in collecting the material. We thank M. Klein (CORSAN) for kindly sending us the subsurface data obtained from the wells drilled in Mata. Anonymous referees are also gratefully acknowledged for their assistance with improving the text.

\section{CONTRIBUTIONS}

A.M.S and M.G.S. conducted the paleobotanical analyses; E.G.B. conducted the GPR analyses; C.L.S. wrote the geological synthesis and established the stratigraphic interpretation of the GPR results.

\section{REFERENCES}

Abreu, V.S.; Neal, J. \& Vail, P.R. 2010. Integration of sequence stratigraphy concepts. In: V.S. Abreu; J. Neal; K.M. Bohacs \& J.L. Kalbas (eds.) Sequence Stratigraphy of Siliciclastic Systems - the ExxonMobil Methodology: Atlas of Exercises, Society for Sedimentary Geology, p. 209-224.

Andreis, R.R.; Bossi, G.E. \& Montardo, D.K. 1980. O Grupo Rosário do Sul (Triássico) no Rio Grande do Sul, Brasil. In: CONGRESSO BRASILEIRO DE PALEONTOLOGIA, 31, 1980. Anais, Camboriú, SBG, p. 659-673.

Araújo, D.C. \& Gonzaga, T.D. 1980. Uma nova espécie de Jachaleria (Therapsida Dicynodontia) do Triássico do Brasil. In: CONGRESSO ARGENTINO DE PALEONTOLOGIA E BIOESTRATIGRAFIA, 2, CONGRESSO LATINO AMERICANO DE PALEONTOLOGIA, 1, 1980. Actas, Buenos Aires, p. 159-174.

Aist, J.R. 1976. Papillae and related wound plugs of plant cells. Annual Review of Phytopathology, 14:145-163. doi:10.1146/ annurev.py.14.090176.001045

Ash, S.R. \& Creber, G.T. 1990. Paleoclimatic interpretation of the wood structure of the trees in Petrified Forest National Park, Arizona: a progress report. Geological Society of America, Abstracts with Programs, 22:4.

Ash, R.S. \& Creber, G.T. 1992. Palaeoclimatic interpretation of the wood structures of the trees in the Chinle Formation (Upper Triassic), Petrified Forest National Park, Arizona, USA. Palaeogeography, Palaeoclimatology, Palaeoecology, 96:299-317. doi:10.1016/0031-0182(92)90107-G

Baas, P. \& Schweingruber, F.H. 1987. Ecological trends in the wood anatomy of trees, shrubs and climbers in Europe. IAWA Bulletin, 8:245-287. doi:10.1163/22941932-90001053 
Barboni, R. \& Dutra, T.L. 2013. New "flower" and leaves of Bennettites from Southern Brazil and their implication in the age of the lower Mesozoic deposits. Ameghiniana, 50:14-32. doi:10.5710/AMGH.28.11.2012.444

Barboza, E.G.; Rosa, M.L.C.C.; Dillenburg, S.R.; Biancini da Silva, A. \& Tomazelli, L.J. 2014. Stratigraphic analysis applied on the recognition of the interface between marine and fluvial depositional systems. Journal of Coastal Research, 70:205-210. doi:10.2112/SI70-116.1

Bardola, T.P. 2011. Caracterização anatômica e relações estatigráficas entre a lignoflora triássica da região de São Pedro do Sul, RS. Universidade Federal do Rio Grande do Sul, B.S. thesis, $61 \mathrm{p}$.

Bardola, T.P.; Schmidt, I.D.; Guerra-Sommer, M. \& Schultz, C. 2009. Lenhos de Gynkgophyta em florestas petrificadas no Triássico superior sul-rio-grandense, Brasil. Revista Brasileira de Paleontologia, 12:1939-1948. doi:10.4072/rbp.2009.2.04

Blanchette, R.A.; Nilsson, T.; Daniel, G. \& Abad, A. 1990. Biological degradation of wood. In: R.M. Rowell \& R.J. Barbour (eds.) Archaeological wood: properties, chemistry and preservation, American Chemical Society, p. 141-174.

Bonello, P.; Gordon, T.R.; Herm, D.A.; Wood, D.L. \& Erbilgin, N. 2006. Nature and ecological implications of pathogen-induced systemic resistance in conifers: a novel hypothesis. Physiological and Molecular Plant Pathology, 68:95-104. doi:10.1016/j. pmpp.2006.12.002

Bortoluzzi, C.A. 1974. Contribuição à geologia da região de Santa Maria, Rio Grande do Sul, Brasil. Pesquisas em Geociências, 4:7-86.

Butler, D.R. \& Sawyer, C.F. 2008. Dendrogeomorphology and highmagnitude snow avalanches: a review and case study. Natural Hazards and Earth System Science, 8:303-309. doi:10.5194/ nhess-8-303-2008

Creber, G.T. \& Chaloner, W.G. 1984. Climate indications from growth rings in fossil structure of living and fossil trees. The Botanical Review, 50:357-448.

Crisafulli, A. \& Dutra, T.L. 2009. Kaokoxylon zalesskyi (Sahni) Maheswari en los niveles superiores de la Secuencia Santa Maria 2 (Formación Caturrita), Cuenca de Paraná, Brasil. GAEA, 5:61-69. doi:10.4013/gaea.2009.52.02

Crisafulli, A.; Dutra, T.L. \& Herbst, R. 2016. In-situ Late Triassic fossil woods from the fluvial channel deposits of the Caturrita Formation, Faxinal do Soturno, Rio Grande do Sul, Brazil. GAEA, 9:37-46. doi:10.4013/gaea.2016.91.03

Crisafulli, A.; Herbst, R. \& Dutra, T.L. 2018. New gymnosperm wood fossil, a seed-ovule structure, and a new generic affinity to Cedroxylon canoasense Rau from the Permian and TriassicJurassic of Southern Brasil. Revista Brasileira de Paleontologia, 21:47-62. doi:10.4072/rbp.2018.1.03

Davis, J.L. \& Annan, A.P. 1989. Ground-penetrating radar for highresolution mapping of soil and rock stratigraphy. Geophysical Prospecting, 37:531-551. doi:10.1111/j.1365-2478.1989. tb02221.x

Decombeix, A-L.; Serbet, R. \& Taylor, E.L. 2018. Under pressure? Epicormic shoots and traumatic growth zones in high-latitude Triassic trees from East Antarctica. Annals of Botany, 121:681689. doi:10.1093/aob/mcx199

Del Fueyo, G.M.; Taylor, E.L.; Taylor, T.N. \& Cúneo, N.R. 1995. Triassic wood from the Gordon Valley, Central Transantarctic Mountains, Antarctica. IAWA Journal, 16:111-126.

Dentzien-Dias, P.C.; Schultz, C.L.; Scherer, C.M.S. \& Lavina, E.L.C. 2007. The trace fossil record from the Guará Formation (Upper Jurassic?), Southern Brazil. Arquivos do Museu Nacional, 65:585-600.
Dietrich, D.; Lampke, T. \& Rößler, R. 2013. A microstructure study on silicified wood from the Permian Petrified Forest of Chemnitz. Paläontologische Zeitschrift, 87:397-407. doi:10.1007/s12542012-0162-0

Douglass, A.E. 1928. Climatic cycles and tree growth. Vol. 2: a study of the annual rings in trees in relation to climate and solar activity. Washington, Carnegie Institution of Washington, $127 \mathrm{p}$.

Drees, B.M.; Jackman, J.A. \& Merchant, M.E. 2006. Wood-boring insects of trees and shrubs. Available at http://www.spcbtx.org/ consumer/woodtrees.pdf; accessed on 05/06/2020.

Faccini, U.F. 1989. O Permo-Triássico do Rio Grande do Sul. Programa de Pós-Graduação em Geociências, Universidade Federal do Rio Grande do Sul, M.Sc. thesis, $121 \mathrm{p}$.

Falcon-Lang, H.J. 2003. Growth interruptions in silicifed conifer woods from the Upper Cretaceous Two Medicine Formation, Montana, USA: implications for palaeoclimate and dinosaur palaeoecology. Palaeogeography, Palaeoclimatology, Palaeoecology, 199:299314. doi:10.1016/S0031-0182(03)00539-X

Fritts, H.C. 1976. Tree rings and climate. San Franscisco, Academic Press, $582 \mathrm{p}$.

Gärtner, H. \& Heinrich, I. 2013. Glacial landforms, tree rings: dendrogeomorphology. In: S. Elias (ed.) The Encyclopedia of Quaternary Science, Elsevier, p. 91-103. doi:10.1016/B978-0444-53643-3.00356-3

Gnaedinger, S.; García-Massini, J.L.; Bechis, F. \& Zavattieri, A.M. 2015. Coniferous woods and wood-decaying fungi from the El Freno Formation (Lower Jurassic), Neuquén Basin, Mendoza Province, Argentina. Ameghiniana, 52:447-467. doi:10.5710/ AMGH.12.05.2015.2868

Gnaedinger, S. \& Zavattieri, A.M. 2020. Coniferous woods from the Upper Triassic of southwestern Gondwana, Tronquimalal Group, Neuquén Basin, Mendoza Province, Argentina. Journal of Paleontology, 94:1-30. doi:10.1017/jpa.2020.1

Gordon Jr., M. 1947. Classificação das formações gondwânicas do Paraná, Santa Catarina e Rio Grande do Sul. Notas Preliminares e Estudos, 81:1-19.

Greguss, P. 1972. Xylotomy of the living conifers. Budapest, Akadémiai Kiadó, 172 p.

Guerrra-Sommer, M. \& Scherer, C.M.S. 2002. Sítios paleobotânicos do arenito Mata (Mata e São Pedro do Sul), RS. Uma das mais importantes "florestas petrificadas" do planeta. In: C. Schobbenhaus, D.A. Campos, E.T. Queiroz, M. Winge \& M.L.C. Berbert-Born (eds.) Sitios Geológicos e Palinológicos do Brasil, DNPM/CPRM/SIGEP, p. 1-8.

Horn, B.L.D.; Goldberg, K. \& Schultz, C.L. 2018a. A loess deposit in the Late Triassic of southern Gondwana, and its significance to global paleoclimate. Journal of South American Earth Sciences, 81:189-203. doi:10.1016/j.jsames.2017.11.017

Horn, B.L.D.; Goldberg, K. \& Schultz, C.L. 2018b. Interpretation of massive sandstones in ephemeral fluvial settings - a case study from the upper Candelaria Sequence (Upper Triassic, Paraná Basin, Brazil). Journal of South American Earth Sciences, 81:108-121. doi:10.1016/j.jsames.2017.10.009

Horn, B.L.D.; Melo, T.M.; Schultz, C.L.; Philipp, R.P. \& Goldberg, K. 2014. A new third-order sequence stratigraphic framework applied to the Triassic of the Paraná Basin, Rio Grande do Sul, Brasil, based on structural, stratigraphic and paleontological data. Journal of South American Earth Sciences, 55:123-132. doi:10.1016/j.jsames.2014.07.007

Huene, F.V. \& Stahlecker, R. 1931. Observações geológicas no Rio Grande do Sul. Boletim do Instituto de Ciências Naturais da Universidade de Santa Maria, 3:3-99. 
IAWA Committee. 2004. IAWA list of microscopic features for softwood identification. IAWA Journal, 25:1-70.

Jenisch, A.G.; Lehn, I.; Gallego, O.F.; Monferran, M.D.; Horodyski, R.S. \& Faccini, U.F. 2017. Stratigraphic distribution, taphonomy and paleoenvironments of Spinicaudata in the Triassic and Jurassic of the Paraná Basin. Journal of South American Earth Sciences, 80:1-20. doi:10.1016/j. jsames.2017.09.022

Leandro, C.G.; Barboza, E.G.; Caron, F. \& Jesus, F.A.N. 2019. GPR trace analysis for coastal depositional environments of southern Brazil. Journal of Applied Geophysics, 162:1-12. doi:10.1016/j. jappgeo.2019.01.002

Milani, E.J. 1997. Evolução tectono-estratigráfica da Bacia do Paraná e seu relacionamento com a geodinâmica fanerozóica do Gondwana sul-ocidental. Programa de Pós-Graduação em Geociências, Universidade Federal do Rio Grande do Sul, Ph.D. thesis, $255 \mathrm{p}$.

Minello, L.F. 1994. As "Florestas Petrificadas" da região de São Pedro do Sul e Mata, RS. III. Análise morfológica megascópica, afinidades e considerações paleoambientais. Acta Geológica Leopoldensia, 39:75-91.

Moraes-Rego, L.F. 1930. Geologia do petróleo no Estado de São Paulo. Boletim do Serviço Geológico e Mineralógico, 46:1-105.

Neal, A. 2004. Ground-penetrating radar and its use in sedimentology: principles, problems and progress. Earth-Science Reviews, 66:261-330. doi:10.1016/j.earscirev.2004.01.004

Philippe, M. \& Bamford, M. 2008. A key to morphogenera used for Mesozoic conifer-like woods. Review of Palaeobotany and Palynology, 148:184-207. doi:10.1016/j.revpalbo.2007.09.004

Pires, E.F.; Guerra-Sommer, M. \& Scherer, C.M.S. 2005. Late Triassic climate in Southern most Parana Basin (Brazil): evidence from dendrochronological data. Journal of South American Earth Sciences, 18:213-221. doi:10.1016/j.jsames.2004.10.004

Preto, N.; Kustatscher, E. \& Wignall, P.B. 2010. Triassic climates - State of the art and perspectives. Palaeogeography, Palaeoclimatology, Palaeoecology, 290:1-10. doi:10.1016/j. palaeo.2010.03.015

Pujana, R.R.; García-Massini, J.L.; Brizuela, R.R. \& Burrieza, H.P. 2009. Evidence of fungal activity in silified gymnosperm wood from the Eocene of southern Patagonia (Argentina). Geobios, 42:639-647. doi:10.1016/j.geobios.2009.05.001

Robinson, P.L. 1973. Paleoclimatology and continental drift. In: D.H. Tarling \& S.K. Runcorn (eds.) Implications of continental drift to the Earth Sciences, Academic Press, p. 449-476.

Rohn, R.; Dutra, T.L. \& Cabral, M.V.B. 2014. Conchostráceos como evidência de níveis jurássicos na Formação Caturrita, Faxinal do Soturno, Rio Grande do Sul, Brasil. Geologia USP, Série Cientifica, 14:3-20. doi:10.5327/Z1519-874X201400010001

Ryberg, P.E. \& Taylor, E.L. 2007. Silicified wood from the Permian and Triassic of Antarctica: tree rings from polar paleolatitudes. In: A.K. Cooper; P.J. Barrett; H. Stagg; B. Storey; E. Stump; W. Wise \& 10th ISAES ed. team (eds.) Antarctica: a keystone in a changing world, proceedings of the 10th International Symposium on Antarctic Earth Sciences, National Academies Press, Paper 080. doi:10.3133/of2007-1047.srp080
Sagasti, A.J.; García-Massini, J.L.; Escapa, I.H. \& Guido, D.M. 2019. Multitrophic interactions in a geothermal setting: arthropod borings, actinomycetes, fungi and fungal-like microorganisms in a decomposing conifer wood from the Jurassic of Patagonia. Palaeogeography, Palaeoclimatology, Palaeoecology, 514:3144. doi:10.1016/j.palaeo.2018.09.004

Schwarze, F.W.M.R. 2007. Wood decay under the microscope. Fungal Biology Reviews, 21:133-170. doi:10.1016/j.fbr.2007.09.001

Schweingruber, F.H. 1992. Annual growth rings and growth zones in woody plants in southern Australia. IAWA Journal, 13:359-379.

Schweingruber, F.H. 1996. Tree rings and environment dendroecology. Bern, Paul Hapt, 609 p.

Schweingruber, F.H. 2007. Wood structure and environment. Berlin, Springer, $279 \mathrm{p}$.

Sellwood, B.W. \& Valdes, P.J. 2006. Mesozoic climates: general circulation models and the rock record. Sedimentary Geology, 190:269-287. doi:10.1016/j.sedgeo.2006.05.013

Silva, A.B. 2009. Mapeamento e caracterização dos depósitos em subsuperficie do setor meridional da Planície Costeira Sul de Santa Catarina. Universidade Federal do Rio Grande do Sul, B.S. thesis, $66 \mathrm{p}$.

Snyder, T.E. 1924. A non-subterranean termite in Virginia. Proceedings of the Entomological Society of Washington, 26:207-209.

Soares, P.C.; Soares, A.P. \& Bettú, D.F. 2014. Formação da sequência triássico-jurássica na Bacia do Paraná. Boletim de Geociências da Petrobras, 22:135-160.

Spalletti, L.A.; Arabe, A.E. \& Morel, E.M. 2003. Geological factors and evolution of southwestern Gondwana Triassic plants. Gondwana Research, 6:119-134. doi:10.1016/S1342937X(05) 70648-1

Wang, P.X. 2009. Global monsoon in a geological perspective. Chinese Science Bulletin, 54:1113-1136.

White, I.C. 1908. Relatório final da comissão de estudos das minas de carvão de pedra do Brasil. Rio de Janeiro, Imprensa Nacional, 617 p.

Zerfass, H.; Lavina, E.; Schultz, C.L.; Garcia, A.J.V.; Faccini, U.F. \& Chemale Jr., F. 2003. Sequence stratigraphy of continental Triassic strata of Southernmost Brazil: a contribution to Southwestern Gondwana palaeogeography and palaeoclimate. Sedimentary Geology, 161:85-105. doi:10.1016/S00370738(02)00397-4

Zhang, W. \& Grant-Mackie, J.A. 2001. Late Triassic-Early Jurassic palynofloral assemblages from Murihiku strata of New Zealand and comparisons with China. Journal of the Royal society of New Zealand, 31:575-683. doi:10.1080/03014223.2001.9517668

Ziegler, A.M.; Scotese, C.R. \& Barrett, S.F. 1983. Mesozoic and Cenozoic paleogeographic maps. In: P. Brosche \& J. Sündermann (eds.) Tidal friction and the earth's rotation, Springer-Verlag, p. 240-252.

Received in 30 August, 2020; accepted in 30 October, 2020. 